\title{
Öğretmen Adaylarının Özel Yetenekli Öğrenciyi Aday Gösterme Tercihlerini Etkileyen Faktörler
}

\section{İbrahim AKAR*}

Öz: Bu araştırmanın amacı öğretmen adaylarının özel yetenekli öğrenciyi aday gösterme tercihlerinin farklı değişkenlerden etkilenip etkilenmediklerini ortaya çıkarmaktır. Araştırma dördüncü sınıf düzeyindeki 178 öğretmen adayının katılımıyla gerçekleştirilmiş olup veriler 11 farklı öğrenci profili kullanılarak toplanmıştır. Toplanan veriler, profillere konu olan öğrenci özellikleri ile öğretmen adaylarının sahip oldukları demografik özelliklerin profile konu olan öğrenciyi aday gösterme tercihleri üzerindeki etkileşim etkisini ortaya çıkarmak amacıyla çok faktörlü varyans analizi kullanılarak analiz edilmiştir. Bulgular, öğretmen adaylarının tercihlerinin öğretmen adayının cinsiyeti, özel yetenekli bir yakınının olması ve özel yetenekli bir öğrenciyi gözlemlemiş olması ile öğrencinin merak duyduğu ders, cinsiyeti, merak alanı, merak süresi, yetenek konusu (matematik/okuma), organize olması, dikkati, duyguları, ailede özel yetenek geçmişi ve ailenin ekonomik durumdan etkilendiğini göstermiştir. Araştırma sonucunda öğretmen adaylarının özel yetenekli öğrenciyi aday gösterme tercihlerinde hem kendi hem de profillerde verilen öğrenci özelliklerinden etkilenerek nesnel davranamadıkları ortaya çıkmıştır. Ayrıca, sadece özel eğitim dersi almış olmanın özel yetenekli öğrenci özellikleri ile tanışmada yeterli olmadığı sonucuna da varılmıştır. Araştırma sonucuna paralel olarak uygulamaya ve araştırmaya dönük önerilerde bulunulmuştur.

Anahtar Kelimeler: Özel yetenek, öğretmen adayı, özel yetenekli öğrenci tercihi

\section{Factors that Influence Prospective Teachers’ Gifted Referral Decisions}

Abstract: The purpose of this research study was to investigate the factors that influence prospective teachers' referral decisions for gifted students. Participants were 178 fourth grade prospective teachers. Data were collected via Student Profiles Survey which includes 11 different profiles, and participants were asked to rate each profile on a $4^{\text {th }}$ Likert scale. Multiple factors analysis of variance was used to analyze the interaction effect of participants' profile

\footnotetext{
* Dr. Öğr. Üyesi, Kastamonu Üniversitesi Eğitim Fakültesi C Blok Kat-3 Merkez/Kastamonu, E-posta: iakar@kastamonu.edu.tr , brhmkr@gmail.com , Orcid ID: 0000-0001-5147-129X
} 
rates between their demographic properties and student characteristics embedded in profiles. Findings revealed that prospective teachers' referral decisions were influenced by their gender, having a relative/being familiar someone identified as gifted, having observed a gifted student and students' gender, subject, area of passion, length of passion, ability(math/reading), organization, attention, emotion, economic status and family history in gifted education. In conclusion, participant prospective teachers' have possession of stereotypical views and prejudgments, and these influenced them being biased in their referral decisions. Besides, having taken only the special education course seemed to be insufficient to help prospective teachers in meeting with characteristics of gifted students. A number of recommendations for practice and future research were developed in parallel with research conclusion.

Keywords: Gifted student, prospective teachers, referral decisions

\section{Giriş}

Özel yetenekli olmak farklı kesimler için farklı anlamlar taşıyabilmektedir. Henüz üzerinde görüş birliğine varılmış ortak bir tanıma sahip olmayan özel yeteneğin; tanılanması da farklı şekillerde gerçekleşebilmektedir. Tanılama sürecinin başlaması da genellikle öğrencideki özel yetenekli olma potansiyelinin fark edilmiş ya da keşfedilmiş olmasıyla mümkün olabilmektedir. Özel yetenek potansiyeli taşıyan öğrencilerin özel yetenekli olarak tanılanmaları ve yetenek destekleme programlarına erişim sağlamaları da sıklıkla, onlardaki potansiyeli fark edecek olan öğretmenlerin özel yeteneğe ve özel yetenekli öğrenciye ilişkin görüşleri, algıları, inanışları, kalıpları, önyargıları ve beklentilerine bağımlı bir şekilde gerçekleşebilmektedir. Bu duruma okul ve eğitim sistemleri çerçevesinden bakıldığında, tanılama öncesinde kritik bir aşama olan aday gösterme süreci devreye girmektedir. Bu süreçte öğretmenlere belirgin roller verilmektedir.

Türkiye’de, Milli Eğitim Bakanlığına bağlı Bilim ve Sanat Merkezlerince yapılan 20182019 yılı tarama ve tanılama sürecine bakıldığında Bakanlıkça belirlenen hedef kitlenin ilkokul 1., 2. ve 3. sınıf öğrenciler olduğu ve ilkokul düzeyindeki öğrenciler arasından belirgin potansiyele sahip olanların sınıf öğretmenleri tarafından gözlem formları aracılığıyla değerlendirilip aday gösterme işlemi gerçekleştirilerek merkezlerin tanılama süreçlerine yönlendirildikleri belirtilmektedir (MEB, 2018). Ancak, ilgili Bilim ve Sanat Merkezleri Yönergesinin (MEB, 2016) sekizinci maddesinin ikinci ve üçüncü fikrasında Bakanlıkça belirlenen tanılama yaşı veya seviyesi dışında da genel zihinsel, görsel sanatlar ve müzik alanlarında özel yetenek potansiyeline sahip olan öğrencilerin aday gösterilerek tanılama 
sürecine yönlendirilebileceği vurgulanmaktadır. Buradan anlaşılacağı üzere özel yetenek potansiyeline sahip öğrencilerin sadece sınıf öğretmenleri tarafından değil de; farklı eğitim seviyelerinde görev yapan branş öğretmenleri tarafından da keşfedilmeleri beklenmektedir. Tanılama sürecinin başlayabilmesi öncelikli olarak öğretmenlerin öğrencideki potansiyeli fark etme/tarama ve gönderme (tanılamaya aday gösterme) olarak adlandırılan özel eğitimde değerlendirme sürecinin ilk iki aşamasını (Gürsel, 2008) gerçekleştirerek, aday gösterme işlemini doğru ve nesnel olarak yerine getirmeye ne kadar hazır bulundukları ile bağlantılı olarak görülebilir.

Özel yetenekli öğrenciler konusunda öğretmenlerle yapılmış olan farklı araştırmaların bulguları incelendiğinde bu bağlantının yönü hakkında fikir edinmek mümkün görünmektedir. Araştırmalardan elde edilen bulgular, öğretmenlerin özel yetenekli öğrenciler hakkında yeterli bilgiye sahip olmadıklarını, özel yetenekli olmayı ders başarısı ile ilişkilendirdiklerini ve özel yetenekli öğrencileri doğru aday gösterme başarılarının da düşük düzeyde olduğunu göstermiştir (Akar ve Şengil-Akar, 2012; Akar ve Uluman, 2013; Betts ve Neihart, 1988; Dağlığlu, 1995; Gear, 1976; Gökdere ve Ayvacı, 2004; Jacobs, 1971; Pegnato ve Birch, 1959; Rohrer, 1995; Schack ve Starko, 1990). Buna ek olarak bazı farklı araştırmalar öğretmenlerin özel yetenekli öğrenciyi aday gösterme tercihlerine odaklanmış olup tercihlerin; cinsiyet (Bianco, Harris, Garrison-Wade ve Leech, 2011), dezavantaja sahip olma (Bianco, 2005; Bianco ve Leech, 2010), merak, sosyo-ekonomik durum ve akademik olarak güçlü olduğu alanlar (Siegle, Moon, Mann ve Wilson, 2010); matematik becerisi (Siegle ve Powell, 2004); ve etnik kökenden (Elhoweris, Mutua, Alsheikh ve Holloway, 2005) etkilendiklerini ortaya koymuştur. Ayrıca, öğretmenlerin genel öğrenci tercihlerine yönelik olarak yapılan bazı araştırmaların bulguları da öğretmenlerin öznel davranarak; erkek ya da kadın öğretmenlerin her ikisinin de erkek öğrencilerle daha fazla etkileşimde bulunduklarına işaret etmektedir (Koca, 2009; Olivares ve Rosenthal, 1992; Sadker ve Sadker, 1993). Bunun yanı sıra, öğretmenler sosyo-ekonomik olarak üst seviyeden gelen öğrencilerin zekâ bölümü puanlarını daha yüksek; sosyo-ekonomik olarak alt seviyeden gelen öğrencilerin zekâ bölümü puanlarını ise daha düşük olarak tahmin etmektedirler (Alvidrez ve Weinstein, 1999).

Diğer taraftan, öğretmen adayları ve özel yetenek konusunda Türkiye'de yürütülmüş olan araştırmalar incelendiğinde sınırlı sayıda araştırmanın var olduğu göze çarpmaktadır (Çapan, 2010; Demirhan, Uyanık, Güngören ve Erdoğan, 2016; Duran ve Dağlığlu, 2017; Erdimez, 2017; Evin-Gencel ve Satmaz, 2017; Metin, Şenol ve İnce, 2017; Tortop, 2014; 
Yıldırım ve Öz, 2018). Bu araştırmalar genellikle öğretmen adaylarının özel yetenek algı ile metaforik algılarına ve özel yeteneklilerin eğitimlerine yönelik tutumlarına odaklanmıştır. Bunların dışında sadece bir araştırmada öğretmen adaylarının özel yetenekli öğrenciyi aday gösterme tercihleri araştırılmıştır. Sınıf öğretmeni adayları ile Erdimez’in (2017) yapmış olduğu bu araştırmanın bulgularına göre; aday gösterme tercihlerine özel yetenek profillerinden “ekonomik durum ve ailede özel yetenek geçmişi” değişkenlerine göre farklılaşan profilin en fazla uygun; "cinsiyet ve organize olma" değişkenlerine göre farklılaşan profilin ise en az uygun olduğu belirlenmiştir. Ayrıca, aday gösterme tercihlerinin öğretmen adayının cinsiyeti, öğrencinin cinsiyeti, öğrencinin yetenek alanları, öğrencinin kişisel özellikleri, öğrenciyi betimleyen sözcükler ve öğrencinin merak süresi değişkenlerinden etkilendikleri ortaya çıkarılmıştır. Öğretmen adaylarının da dâhil edildiği ilk özel yetenekli öğrenciyi aday gösterme tercihleri çalışması olan Siegle vd.'nin (2010) yapmış oldukları bir araştırmanın bulguları öğrencinin merakı, sosyo-ekonomik durum ve akademik olarak güçlü olduğu alanların öğretmen olan katılımcıların tercihlerini etkilediğini ortaya çıkarmıştır. Ek olarak öğretmenlerin, öğretmen adaylarına kıyasla profildeki öğrenciyi özel yetenekli olarak görmeye daha az eğilimli oldukları ve öğretmen adaylarının da tercihlerinde ailedeki bir önceki çocuğun özel yetenekli olarak tanılanıp tanılanmamasından etkilendikleri bildirilmiştir.

Öğretmen adayları ile yürütülmüş olan araştırmalar genel olarak değerlendirildiğinde, özel yetenekli öğrencileri keşfetmeleri beklenen potansiyel öğretmenler olarak özel yeteneklilere ve onların eğitimlerine yönelik tutumları ile algılarına odaklanıldığı fakat özel yetenekli öğrenciyi aday gösterme tercihlerine fazla odaklanılmadığı görülmektedir. Dahası, öğretmenlerin özel yetenekli öğrenciyi aday gösterme tercihlerine odaklanılmış olan farklı araştırmaların bulguları öğretmenlerin tercihlerini etkileyen etmenlerin var olduğunu ortaya koymuştur. Buradan hareketle bu araştırma, MEB'in (2017; 2018) ilgili mevzuatlarında da vurgulandı̆̆ı üzere, ileride özel yetenekli öğrencileri keşfetmeleri ve tanılama süreçlerine yönlendirmeleri beklenen öğretmen adaylarının özel yetenekli öğrenciyi aday gösterme tercihlerini etkileyen faktörleri ortaya koymayı amaçlamaktadır. Araştırma sonucunda elde edilecek olan bulgular paralelinde öğretmen adaylarının eğitim almakta oldukları öğretmenlik programlarına ve ileride yürütülecek olan araştırmalara yönelik bazı somut önerilerin geliştirilebileceği düşünülmektedir.

\section{Araştırma Soruları}


1. Öğretmen adayları tarafından en çok ve en az aday gösterilen özel yetenekli öğrenci profilleri hangileridir?

2. Öğretmen adaylarının özel yetenekli öğrenciyi aday gösterme tercihleri hangi demografik özellikler ile profilde verilen öğrenci özelliklerinden etkilenmektedir?

\section{Yöntem}

\section{Araştırmanın Deseni}

$\mathrm{Bu}$ araştırma tarama modeli niteliğinde nicel bir çalışmadır. Tarama modeli nicel araştırma yaklaşımına giren bir araştırma modeli olup modelin temel amacı belirgin bir kitle ya da evrene ilişkin özelliklerin ortaya çıkarılmasıdır (Fraenkel ve Wallen, 2006). Bu araştırma da öğretmen adaylarının özel yetenekli öğrenciyi aday gösterme tercihlerini etkileyen faktörleri ortaya koymayı amaçlamaktadır.

\section{Katılımcilar}

Araştırmaya, bir devlet üniversitesinin eğitim fakültesinin öğretmenlik programlarının dördüncü sınıfına devam eden 178 öğretmen adayı katılmıştır. Katılımcılar; sınıf eğitimi (\%21), Türkçe eğitimi (\%5), sosyal bilgiler eğitimi (\%7), bilgisayar ve öğretim teknolojileri eğitimi (\%3), matematik eğitimi (\%15), fen bilgisi eğitimi (\%12), okul öncesi eğitimi (\%32) ve resim iş eğitimi (\%5) anabilim dallarında öğrenim görmektedirler. Katılımcıların 139’u (\%78) kadın ve 39'u (\%22) erkektir. Katılımcıların yaşları 20 ila 29 arasında değişmekte olup \%97'si 24 yaş ve altındadır. Katılımcılardan 45'inin (\%25) özel yetenekli olarak tanılanmış bir tanıdığ ya da yakını bulunmakta olup; katılımcıların 57'si (\%32) ise öğretmenlik uygulaması ya da okul deneyimi dersi kapsamında staj yaptığı okullarda özel yetenekli bir öğrenciyi gözlemlemiştir. Ayrıca, katılımcıların tamamı öğretmenlik lisans programlarında zorunlu ders olarak verilen özel eğitim dersini almıştır.

\section{Veri Toplama Aracı}

Öğrenci Profilleri Anketi (ÖPA) kullanılarak veriler toplanmıştır. Bu ankette yer alan profiller, Siegle vd. (2010) tarafından farklı öğrenci senaryoları olarak geliştirilmiş ve beş farklı özel yetenek alanından gelen uzmanlardan oluşan bir panel tarafindan kapsam geçerliği doğrulanmıştır. ÖPA, Erdimez (2017) tarafından Türkçeye uyarlanmıştır. Ankette toplam 11 farklı öğrenci profili yer almaktadır. Her bir profil iki ya da üç farklı değişkene göre farklılaştırılabilmektedir. Bu değişkenler cinsiyet, ders, sınıf düzeyi, matematik yeteneği, 
okuma yeteneği, merak alanı, merak süresi, organize olma, yetenek alanı, kararlılık, dikkat, liderlik, duygular, arkadaş ilişkileri, ekonomik durum ve ailede özel yetenek geçmişi olarak siralanmaktadır.

Birinci profil cinsiyet (Kadir/Keriman) ve derse (hayat bilgisi, Türkçe, matematik, fen bilimleri) göre değişkenlik göstermektedir. İkinci profil cinsiyet (Betül/Bilal) ve sınıf düzeyine (birinci, ikinci, üçüncü, dördüncü) göre değişkenlik göstermektedir. Üçüncü profil cinsiyet (Melek/Mustafa), okuma yeteneğinin olması ve matematik yeteneğinin olmasına göre değişkenlik göstermektedir. Dördüncü profil cinsiyet (Demet/Davut), merak alanı (kartal/köpek) ve merak süresine göre değişkenlik göstermektedir. Beşinci profil cinsiyet (Sami/Selma) ve organize olmaya göre değişkenlik göstermektedir. Altıncı profil cinsiyet (Necip/Nalan), yetenek alanı (matematik/okuma) ve kararlılık değişkenlerine göre değişkenlik göstermektedir. Yedinci profil cinsiyet (Gülay/Galip) ve dikkat seviyesine göre değişskenlik göstermektedir. Sekizinci profil cinsiyet (Leyla/Lokman) ve liderlik yeteneğine göre değişkenlik göstermektedir. Dokuzuncu profil cinsiyet (Ertan/Eylül) ve duygusal olgunluğa göre değişkenlik göstermektedir. Onuncu profil cinsiyet (Cemal/Canan) ve arkadaşlarına yardım etme istekliliğine göre değişkenlik göstermektedir. On birinci profil (Azra) ekonomik durum ve ailede özel yetenek geçmişine göre değişkenlik göstermektedir (Bkz. Ek 1).

Katılımcılara her bir profil sonunda profildeki öğrenciyi özel yetenek programına dahil edip etmeyecekleri sorulmuş ve değerlendirmelerini dörtlü Likert tipinde verilmiş olan seçeneklerden birini seçerek yapmaları istenmiştir. Seçenekler olarak: "4)Kesinlikle dahil ederim, 3) Dahil ederim ama..., 2) Dahil etmem ama..., 1) Kesinlikle dahil etmem” seçenekleri verilmiştir. Anketlerin başında her bir öğretmen adayının cinsiyeti, özel yetenekli olarak tanılanmış bir tanıdığı/yakını olup olmadığı ile okul deneyimi ya da öğretmenlik uygulaması kapsamında özel yetenekli bir öğrenciyi gözlemleyip gözlemlemedikleri sorulmuştur. Her bir katılımcının profillerde yer alan öğrencileri bireysel olarak değerlendirdikleri varsayılmıştır.

\section{Verilerin Toplanması}

ÖPA'da yer alan her bir profil farklı öğrenci özelliklerine göre dönüştürülerek farklı anketler halinde kullanılmıştır (Bkz Ek 1). Anketler Google dokümanlar aracılığıyla sanal ortama aktarılmış ve her bir anket için farklı bağlantılar kullanılarak katılımcılara ulaştırılmıştır. Anketlerin katılımcılara dağıtılması rassal olarak yapılmıştır. Katılımcılar anketleri sanal ortamda doldurup göndermiştir. 


\section{Verilerin Çözümlenmesi}

Toplanan veriler elektronik ortamdan alınıp birleştirilerek tek bir veri dosyası haline getirilmiştir. Eksik veri olup olmadı̆̆ı kontrol edilerek katılımcıların anketleri eksiksiz doldurdukları görülmüştür. Sonrasında ise veriler analiz programına uyumlu bir biçime dönüştürülmüştür. Veri analizinde profillerin en az ve en çok tercih edilme düzeylerini karşılaştırmak için ortalama ve standart sapma hesaplamaları yapılmıştır. Özel yetenekli öğrenciyi aday gösterme tercihlerinin profillerdeki değişkenler ve katılımcıların demografik değişkenlerinden etkilenme durumunu ortaya koymak için ise tek istatistiksel çözümleme seçeneği olan üç ve dört faktörlü varyans analizi yapılmıştır. Parametrik bir analiz tekniği olan bu analize ilişkin varsayımların karşılanıp karşılanmadığını belirlemek için normal dağılım ve varyansların homojenliğine yönelik ön analizler yapılmıştır. Ön analizler sonucunda, Q-Q grafiği (Bkz. Şekil 1) ile çarpıklık $(0,009)$ ve basıklık $(0,085)$ değerlerinin dağılımın normal olduğuna ve Levene testi sonucuna göre de hata varyanslarının eşit olmadığına $(F=2,201$, $\mathrm{p}=0,090$ ) işaret ettiği görülmüş olup varsayımların sağlandığı tespit edilmiştir.

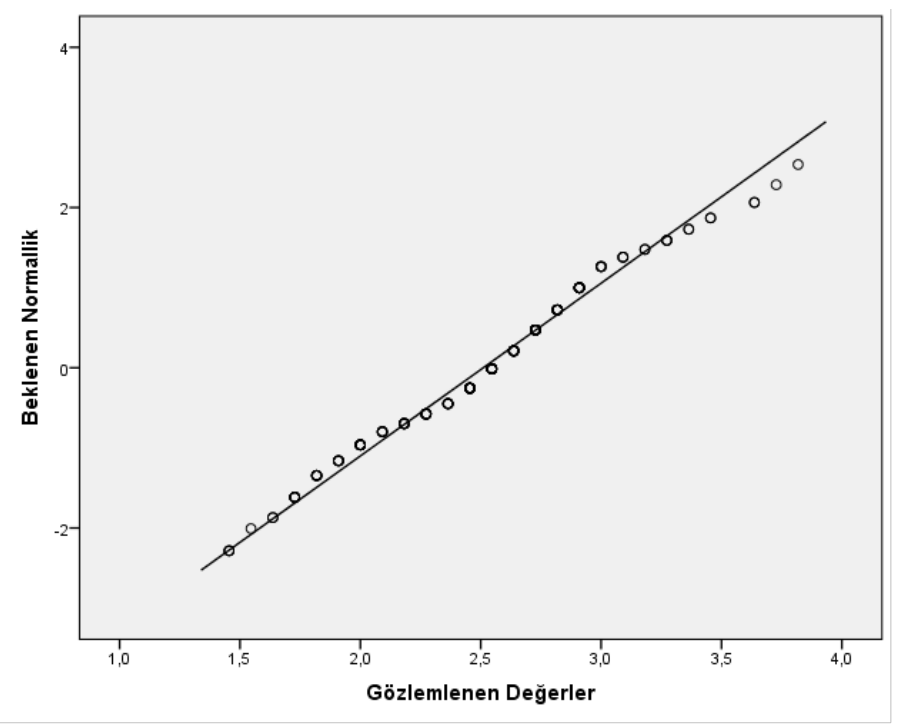

Şekil 1. Profil Ortalamalarının Q-Q Grafiği Gösterimi

\section{Bulgular}

Bu araştırmada yanıtlanmaya çalışılan iki araştırma sorusu sırasıyla aşağıda yanıtlanmış ve bulgular yorumlanmıştır.

\section{Öğretmen Adayları Tarafından En Çok ve En Az Aday Gösterilen Özel Yetenekli Öğrenci Profilleri Hangileridir?}


Öğretmen adaylarının hangi profilleri en az ve en çok aday gösterdiklerini belirlemek için her bir profilin ortalamaları diğer profillerin ortalamaları ile karşılaştırılmış olup ortalama olarak en yüksek ve en düşük değerleri alan belirlenmiştir (Bkz. Tablo 1).

Tablo 1. Öğrenci Profillerinin Genel Olarak Tercih Edilme İstatistikleri

\begin{tabular}{cccc}
\hline $\begin{array}{c}\text { Ögrrenci } \\
\text { Profili }\end{array}$ & $\overline{\mathbf{X}}$ & $\mathbf{S}$ & $\mathbf{N}$ \\
\hline 1 & 2,82 & 0,90 & 178 \\
2 & 3,03 & 0,97 & 178 \\
3 & 2,32 & 0,95 & 178 \\
4 & 2,22 & 1,01 & 178 \\
5 & 2,61 & 1,02 & 178 \\
6 & 1,88 & 0,89 & 178 \\
7 & 2,86 & 1,00 & 178 \\
8 & 2,67 & 1,06 & 178 \\
9 & 2,17 & 1,10 & 178 \\
10 & 2,30 & 0,96 & 178 \\
11 & 2,73 & 0,97 & 178 \\
\hline
\end{tabular}

Tablo 1 incelendiğinde en çok aday gösterilen profilin cinsiyet ve sınıf düzeyine göre değişkenlik gösteren ikinci profilin versiyonları olduğu görülmektedir (Bkz Ek 1). En az aday gösterilenin de cinsiyet, yetenek alanı ve kararlılık değişkenlerine göre değişkenlik gösteren altıncı profilin versiyonları olduğu görülmüştür (Bkz Ek 1). En çok ve en az aday gösterilen ikinci ve altıncı profillerin versiyonları ile her bir versiyona ilişkin istatistikler aşağıdaki Tablo 2'de verilmiştir.

Tablo 2. En Çok ve En Az Aday Gösterilen Öğrenci Profili İstatistikleri

\begin{tabular}{llccc}
\hline Tercih & \multicolumn{4}{c}{ İstatistikler } \\
\hline \multirow{3}{*}{ En Çok } & $\mathrm{PV}$ & 2.4 & 2.5 & 2.2 \\
& $\overline{\mathrm{X}}$ & 3,44 & 3,08 & 3,05 \\
& $\mathrm{~S}$ & 0,77 & 0,98 & 0,92 \\
\hline \multirow{3}{*}{ En Az } & $\mathrm{PV}$ & 6.5 & 6.2 & 6.3 \\
& $\overline{\mathrm{X}}$ & 1,82 & 1,73 & 1,71 \\
& $\mathrm{~S}$ & 0,79 & 0,92 & 0,94 \\
\hline PV= Profil ve Versiyonu & & &
\end{tabular}

Tablo 2 incelendiğinde ise profildeki değişkenler kullanılarak oluşturulan farklı versiyonlara göre en fazla aday gösterilenin ikinci profilin dördüncü versiyonu $(\overline{\mathrm{X}}=3,44)$ olduğu; onu takip edenlerin de ikinci profilin beşinci versiyonu $(\overline{\mathrm{X}}=3,08)$ ile ikinci profilin ikinci versiyonu $(\overline{\mathrm{X}}=3,08)$ görülmektedir. En az aday gösterilenin ise altıncı profilin üçüncü 
versiyonu $(\overline{\mathrm{X}}=1,71)$ olduğu ve onu takip edenlerin de altıncı profilin ikinci versiyonu $(\overline{\mathrm{X}}=1,73)$ ile altıncı profilin beşinci versiyonu $(\overline{\mathrm{X}}=1,82)$ oldukları ortaya çıkmıştır. İkinci profil sınıf düzeyi ve cinsiyet değişkenlerine göre farklılaşmakta olup profilin dördüncü versiyonunda dördüncü sınıfa giden bir kız öğrenci; beşinci versiyonunda dördüncü sınıfa giden bir erkek öğrenci ve ikinci versiyonunda ikinci sınıfa giden bir kız öğrenci verilmektedir. Altıncı profil ise ders, cinsiyet ve kararlılık değişkenlerine göre farklılaşmakta olup profilin üçüncü versiyonunda okumaya meraklı ve istekli olan kararlı bir erkek öğrenci; ikinci versiyonunda okumaya meraklı ve istekli olan çekingen bir erkek öğrenci ve beşinci versiyonunda ise okumaya meraklı ve istekli olan çekingen bir kız öğrenci verilmektedir (Bkz Ek 1).

\section{Öğretmen Adayları Özel Yetenekli Öğrenciyi Aday Gösterme Tercihlerinde Hangi Demografik Özellikler İle Öğrenci Özelliklerinden Etkilenmektedir?}

$\mathrm{Bu}$ araştırma sorusunu yanıtlamak amacıyla her bir profil için çok faktörlü varyans analizi yapılmış olup sadece etkileşim etkisinin anlamlı bulunduğu bulgular sunulmuş ve etkileşimler grafiksel gösterimle desteklenmiştir. İlk olarak, öğrencinin merak duyduğu ders ile öğretmen adayının cinsiyeti arasındaki etkileşim etkisi istatistiksel olarak anlamlı bulunmuştur $F(3,168)=3,093, p=0,029, \eta_{\mathbf{p}}^{2}=0,052$. Yapılan izleme testi sonucunda erkek öğretmen adaylarının tercihlerinin öğrencinin merak duyduğu dersler olan hayat bilgisi $(\bar{X}=3,33, \sigma=0,52)$, Türkçe $(\bar{X}=3,86, \sigma=0,38)$, matematik $(\bar{X}=3,22, \sigma=0,67)$ ve fen bilimlerinden $(\bar{X}=2,71, \sigma=1,05)$ etkilenerek; Türkçe ve fen bilimleri dersleri arasında Türkçe dersine merak duyan öğrenci yönünde anlamlı bir farklılık gösterdiği tespit edilmiştir. Kadın öğretmen adaylarının tercihleri ise öğrencinin merak duyduğu dersler olan hayat bilgisi $(\bar{X}=2,67, \sigma=0,99)$, Türkçe $(\bar{X}=2,76$, $\sigma=0,78)$, matematik $(\bar{X}=2,64, \sigma=0,81)$, fen bilimlerinden $(\bar{X}=2,81, \sigma=0,95)$ etkilenmeyip anlamlı bir farklılık göstermemiştir. Kadın ve erkek öğretmen adaylarının öğrencinin merak duyduğu derse göre tercihleri ise sadece Türkçe dersinde farklılık göstermiştir. Bu 2'de gösterilmektedir.

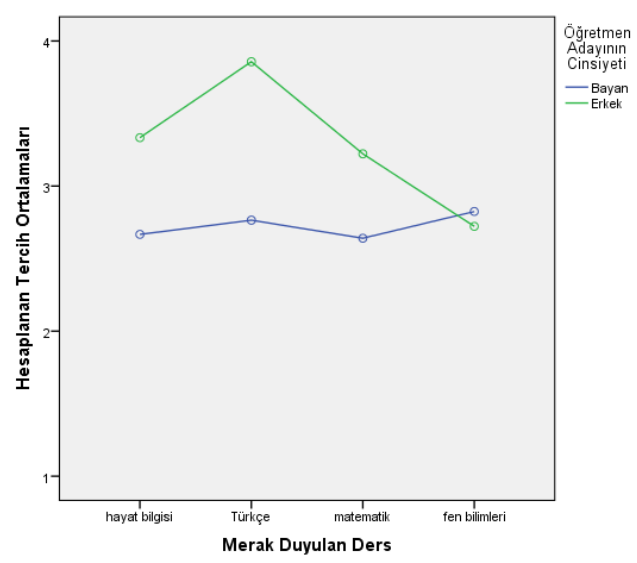
anlamli bir etkileşim Şekil 
Şekil 2. Öğretmen Adaylarının Tercihlerinin Öğretmen Adayının Cinsiyeti ile Öğrencinin Merak Duyduğu Ders Arasındaki Etkileşimi

Şekil 2'deki grafiğe bakıldığında kadın öğretmen adaylarının tercihlerini öğrencinin merak duyduğu ders etkilemezken; erkek öğretmen adaylarının tercihlerini etkilediği ve Türkçe dersine merak duyan öğrenciyi diğer derslere kıyasla daha fazla tercih ettikleri; hayat bilgisi ve matematik dersini de birbirine yakın fakat fen bilimleri dersine kıyasla daha fazla tercih ettikleri görülmektedir. Ayrıca, erkek öğretmen adaylarının; hayat bilgisi, Türkçe ve matematik derslerini kadın öğretmen adaylarına kıyasla daha fazla tercih etmiş olmasına rağmen sadece Türkçe dersindeki fark anlamlı bulunmuştur.

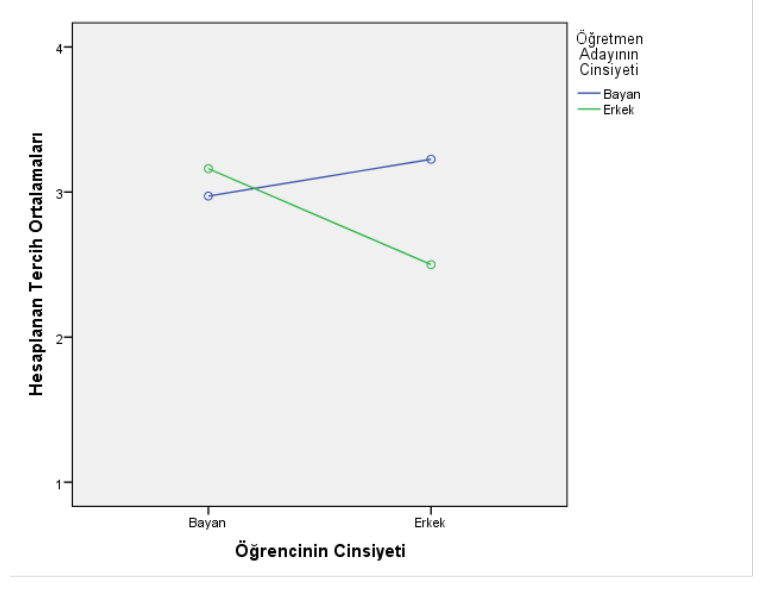

Şekil 3. Öğretmen Adaylarının Tercihlerinin Öğretmen Adayının Cinsiyeti ile Profillerdeki Öğrencinin Cinsiyeti Arasındaki Etkileşimi

İkinci olarak öğrencinin cinsiyeti ile öğretmen adayının cinsiyeti arasındaki etkileşim etkisi istatistiksel olarak anlamlı bulunmuştur $F(1,168)=5,279, p=0,023, \eta_{\mathbf{p}}{ }^{2}=0,030$. Kadın öğretmen adaylarının tercihleri kadın öğrenci $(\bar{X}=2,97, \sigma=0,91)$ ile erkek öğrenci $(\bar{X}=3,23$, $\sigma=0,92)$ arasında erkek öğrenci yönünde; erkek öğretmen adaylarının tercihleri ise kadın öğrenci $(\bar{X}=3,16, \sigma=1,13)$ ile erkek öğrenci $(\bar{X}=2,50, \sigma=1,07)$ arasında kadın öğrenci yönünde anlamlı derecede farklılık göstermiştir. Bu etkileşimin verildiği Şekil 3’teki grafiğe bakıldığında öğretmen adaylarının kendi cinsiyeti ile öğrencinin cinsiyetinden etkilenerek kadın öğretmen adaylarının erkek öğrenciyi; erkek öğretmen adaylarının da kadın öğrenciyi daha fazla tercih ettikleri görülmektedir.

Üçüncü olarak öğrencinin merak alanı ile merak süresi arasındaki etkileşim etkisi istatistiksel olarak anlamlı bulunmuştur $F(1,168)=4,978, p=0,027, \eta_{\mathbf{p}}{ }^{2}=0,029$. Öğretmen 
adaylarının tercihleri anasınıfından itibaren kartallara ilgi duyan öğrenci $(\bar{X}=2,34, \sigma=0,98)$ ile ikinci sınıftan itibaren kartallara ilgi duyan öğrenci $(\bar{X}=2,23, \sigma=1,04)$ arasında anasınıfından itibaren kartallara ilgi duyan öğrenci yönünde anlamlı bir farklılık göstermiştir. Ancak anasınıfından itibaren köpeklere ilgi duyan öğrenci $(\bar{X}=2,12, \sigma=0,95)$ ile ikinci sınıftan itibaren köpeklere ilgi duyan öğrenci $(\bar{X}=2,12, \sigma=1,10)$ arasında anlamlı bir farklılık göstermemiştir. $\mathrm{Bu}$ etkileşim Şekil 4’te verilmiştir.

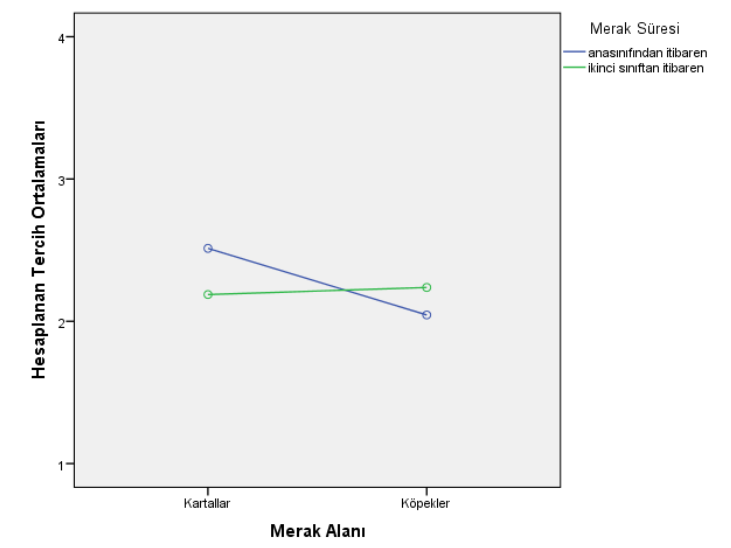

Şekil 4. Öğretmen Adaylarının Tercihlerinin Profildeki Öğrencinin Merak Alanı ile Merak Süresi Arasındaki Etkileşimi

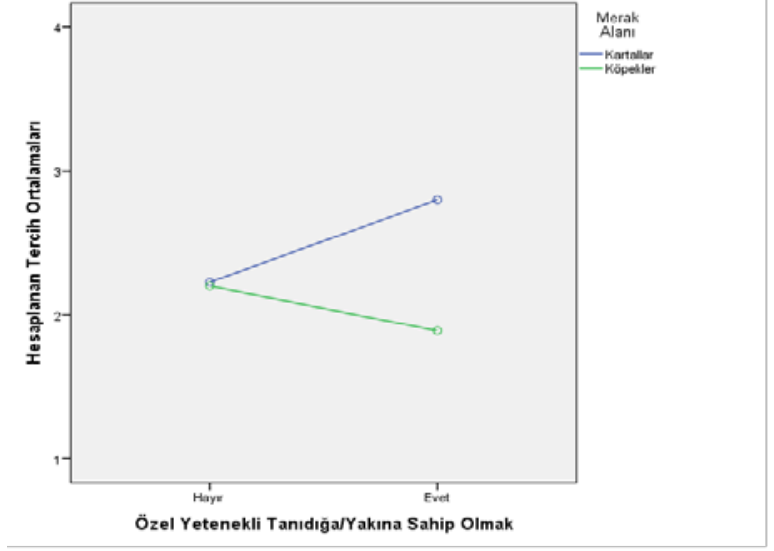

Şekil 5. Öğretmen Adaylarının Tercihlerinin Profíldeki Öğrencinin Merak Alanı Ve Merak Süresi ile Öğretmen Adayının Özel Yetenekli

Tanıdığa/Yakına Sahip Olması Arasındaki Etkileşimi

Şekil 4’teki grafiğge bakıldığında öğretmen adaylarının merak alanı ve merak süresinden etkilenerek köpeklere ikinci sınıftan itibaren ilgi duyan öğrenci ile kartallara anasınıfından itibaren ilgi duyan öğrenciyi daha fazla tercih ettikleri anlaşılmaktadır. Ayrıca öğrencinin merak alanı ve merak süresi ile öğretmen adayının özel yetenekli olarak tanılanmış bir tanıdığının/yakınının olması arasındaki etkileşim etkisi de istatistiksel olarak anlamlı bulunmuştur $F(1,168)=6,084, p=0,015, \eta_{\mathbf{p}}{ }^{2}=0,035$ (Bkz. Şekil 5). Öğretmen adaylarının anasınıfından itibaren köpeklere ilgi duyan öğrenci tercihleri, özel yetenekli olarak tanılanmış bir tanıdığı/yakını olan öğretmen adayları $(\bar{X}=1,89, \sigma=0,78)$ ile özel yetenekli olarak tanılanmış bir tanıdığı/yakını olmayan öğretmen adayları $(\bar{X}=2,20, \sigma=1,00)$ arasında özel yetenekli olarak tanılanmış bir tanıdığı/yakını olmayan öğretmen adayları yönünde anlamlı bir farklılık göstermiştir. Anasınıfından itibaren kartallara ilgi duyan öğrenci tercihleri ise özel yetenekli olarak tanılanmış bir tanıdığı/yakını olan öğretmen adayları $(\bar{X}=2,76, \sigma=1,03)$ ile özel yetenekli olarak tanılanmış bir tanıdığı/yakını olmayan öğretmen adayları $(\bar{X}=2,19, \sigma=0,92)$ arasında özel yetenekli olarak tanılanmış bir tanıdığı/yakını olan öğretmen adayları yönünde anlamlı bir farklılık göstermiştir. Bu etkileşimin verildiği Şekil 5'teki grafiğe bakıldığında özel yetenekli 
tanıdığı/yakını olmayan öğretmen adaylarının merak alanı ve merak süresinden etkilenmedikleri anlaşılmaktadır. Özel yetenekli tanıdığı/yakını olan öğretmen adaylarının ise merak alanı ve merak süresinden etkilenerek anasınıfından itibaren merak alanı kartal olan öğrenciyi daha fazla tercih ettikleri anlaşılmaktadır.

Dördüncü olarak ise öğrencinin cinsiyeti ve organize olması arasındaki etkileşim etkisi istatistiksel olarak anlamlı bulunmuştur $F(1,170)=4,172, p=0,043, \eta_{\mathbf{p}}{ }^{2}=0,024$. Öğretmen adaylarının tercihleri profildeki öğrencinin düzenli bir erkek öğrenci olması $(\bar{X}=2,44, \sigma=0,94)$ ile düzensiz bir erkek öğrenci olması $(\bar{X}=2,90, \sigma=1,02)$ arasında düzensiz erkek öğrenci yönünde anlamlı bir farklılık göstermiştir. Ancak, tercihler profildeki öğrencinin düzenli bir kadın öğrenci olması $(\bar{X}=2,58, \sigma=1,02)$ ile düzensiz bir kadın öğrenci olması $(\bar{X}=2,50, \sigma=1,03)$ arasında anlamlı bir farklılık göstermemiştir. Bu etkileşim Şekil 6’da verilmiştir.

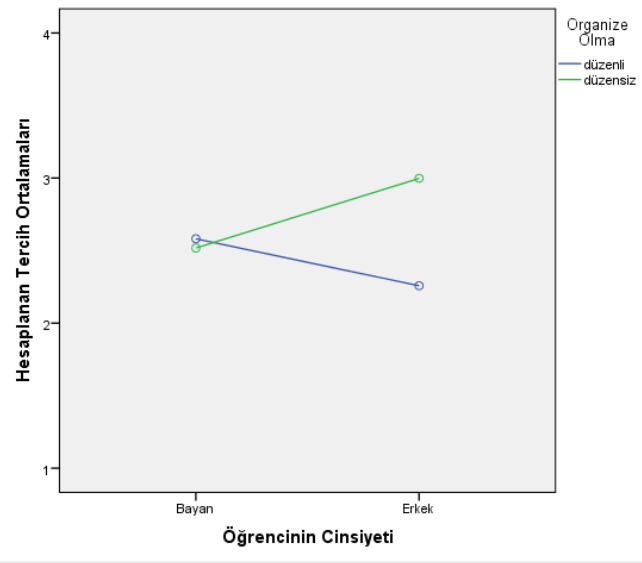

Şekil 6. Öğretmen Adaylarının Tercihlerinin Profildeki Öğrencinin Cinsiyeti ve Organize Olması Arasındaki Etkileşimi

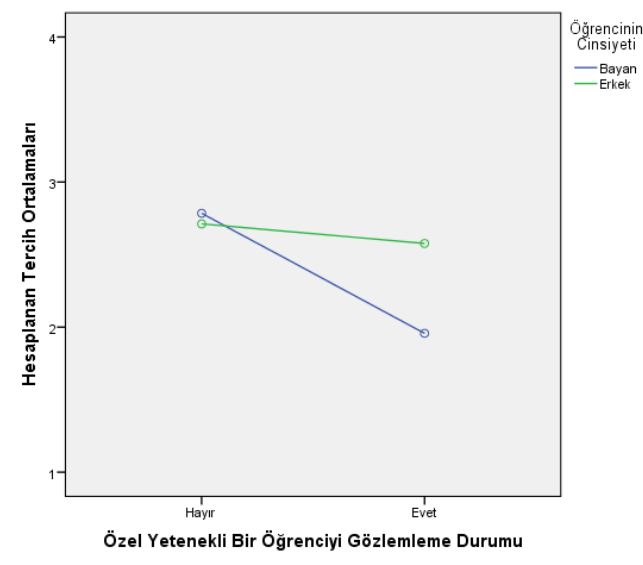

Şekil 7. Öğretmen Adaylarının Tercihlerinin Profildeki Öğrencinin Cinsiyeti ve Öğretmen Adayının Özel Yetenekli Öğrenci Gözlemleme Durumu Arasındaki Etkileşimi

Şekil 6'daki grafiğe bakıldığında öğretmen adaylarının tercihlerinin kadın öğrencinin düzenli ya da düzensiz bir öğrenci olmasından etkilenmedikleri görülmektedir. Ancak düzensiz erkek öğrencinin düzensiz kadın öğrenciye göre ve düzenli kadın öğrencinin düzenli erkek öğrenciye göre daha fazla tercih edildikleri görülmektedir. Beşinci olarak da öğrencinin cinsiyeti ve öğretmen adayının özel yetenekli bir öğrenciyi gözlemlemiş olması arasındaki etkileşim etkisi istatistiksel olarak anlamlı bulunmuştur $F(1,170)=4,455, p=0,036, \eta_{\mathbf{p}}{ }^{2}=0,026$ (Bkz. Şekil 7). Özel yetenekli bir öğrenciyi gözlemlemiş olan öğretmen adaylarının tercihleri profildeki erkek öğrenci $(\bar{X}=2,58, \sigma=0,90)$ ile kadın öğrenci $(\bar{X}=2,03, \sigma=1,08)$ arasında erkek öğrenci yönünde anlamlı bir farklılık göstermiştir. Özel yetenekli bir öğrenciyi gözlemlememiş 
olan öğretmen adaylarının tercihleri profildeki erkek öğrenci $(\bar{X}=2,72, \sigma=1,05)$ ile kadın öğrenci $(\bar{X}=2,79, \sigma=0,91)$ arasında anlamlı bir farklılık göstermemiştir. Bu etkileşimin verildiği Şekil 7’deki grafiğe bakıldığında özel yetenekli bir öğrenciyi gözlemlememiş olan öğretmen adaylarının tercihlerinin öğrencinin erkek ya da kadın olmasından etkilenmedikleri görülmektedir. Ancak öğrenci kadın olduğunda, özel yetenekli bir öğrenciyi gözlemlememiş olan öğretmen adayları tarafından gözlemlemiş olanlara kıyasla daha fazla tercih edildiği görülmektedir.

Altıncı bulgu olarak, öğretmen adaylarının özel yetenekli bir öğrenciyi gözlemleme durumu ile öğrencinin profilde verilen yetenek konusu arasındaki etkileşim etkisi istatistiksel olarak anlamlı bulunmuştur $F(1,170)=5,390, p=0,021, \eta_{\mathbf{p}}{ }^{2}=0,031$. Özel yetenekli bir öğrenciyi gözlemlememiş olan öğretmen adaylarının tercihleri matematik becerileri olan öğrenci $(\bar{X}=2,27, \sigma=0,67)$ ile okumaya istekli ve meraklı olan öğrenci $(\bar{X}=1,77, \sigma=0,88)$ arasında matematik becerileri olan öğrenci yönünde anlamlı bir farklılık göstermiştir. Özel yetenekli bir öğrenciyi gözlemlemiş olan öğretmen adaylarının tercihleri ise matematik becerileri olan öğrenci $(\bar{X}=1,69, \sigma=0,95)$ ile okumaya istekli ve meraklı olan öğrenci $(\bar{X}=1,95, \sigma=0,94)$ arasında okumaya istekli ve meraklı olan öğrenci yönünde anlamlı bir farklılık göstermiştir. Bu etkileşim Şekil 8'de verilmiştir.

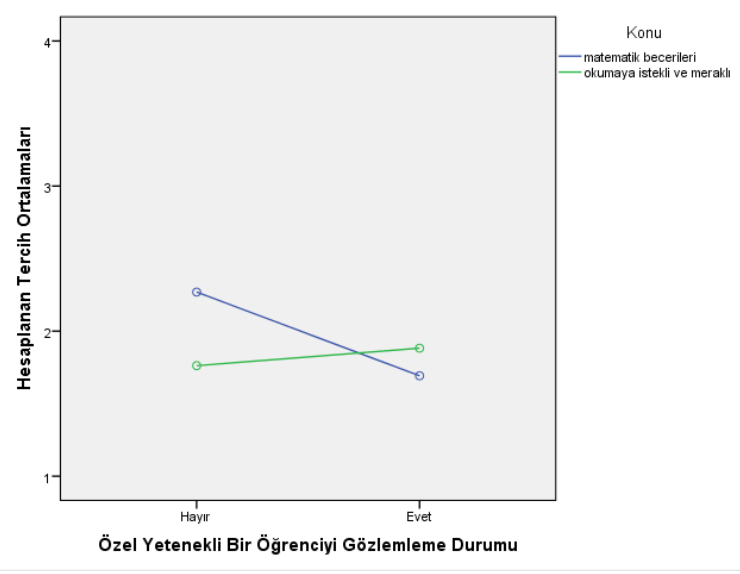

Şekil 8. Öğretmen Adaylarının Tercihlerinin Profilde Verilen Yetenek Konusu ve Öğretmen Adayının Özel Yetenekli Öğrenci Gözlemleme Durumu Arasındaki Etkileşimi

Yukarıdaki grafiğe bakıldığında özel yetenekli bir öğrenciyi gözlemlememiş olanların matematik becerilerine sahip öğrenciden etkilendikleri ve okumaya istekli ve meraklı öğrenciden daha fazla tercih ettikleri görülmektedir. Okumaya istekli ve meraklı öğrencinin 
ise özel yetenekli öğrenciyi gözlemlemiş olan öğretmen adayları tarafından matematik becerilerine sahip öğrenciye kıyasla daha fazla tercih edildiği anlaşılmaktadır.

Yedinci olarak ise öğretmen adayının cinsiyeti ile öğrencinin profilde verilen yetenek konusu arasındaki etkileşim etkisi istatistiksel olarak anlamlı bulunmuştur $F(1,170)=4,224$, $p=0,041, \eta_{\mathbf{p}}{ }^{2}=0,024$. Matematik becerileri olan öğrenci tercihleri kadın öğretmen adayları $(\bar{X}=2,15, \sigma=0,83)$ ile erkek öğretmen adayları $(\bar{X}=1,67, \sigma=0,52)$ arasında kadın öğretmen adayları yönünde anlamlı bir farklılık göstermiştir. Okumaya istekli ve meraklı olan öğrenci tercihleri ise kadın öğretmen adayları $(\bar{X}=1,80, \sigma=0,88)$ ile erkek öğretmen adayları $(\bar{X}=1,91$, $\sigma=0,98)$ arasında erkek öğretmen adayları yönünde anlamlı bir farklılık göstermiştir. $\mathrm{Bu}$ etkileşim Şekil 9'da verilmiştir.

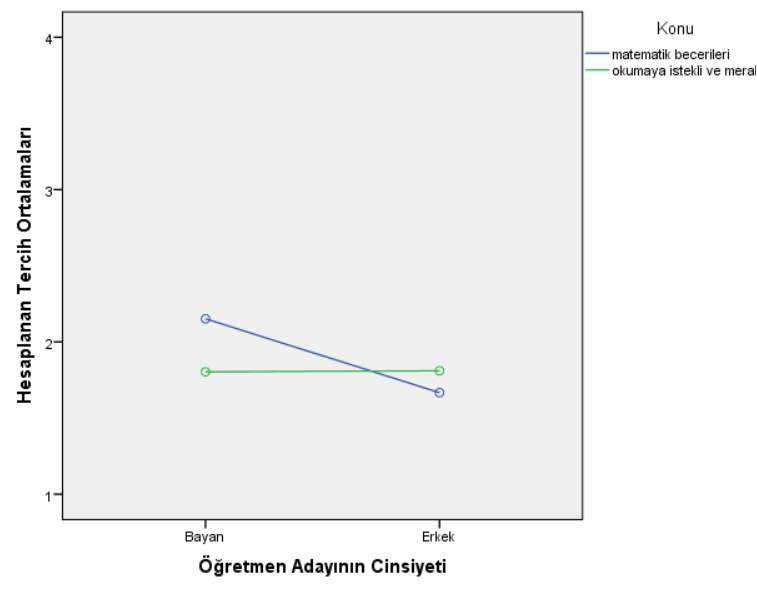

Şekil 9. Öğretmen Adaylarının Tercihlerinin Profilde Verilen Özellik Konusu ve Öğretmen Adayının Cinsiyeti Arasındaki Etkileşimi

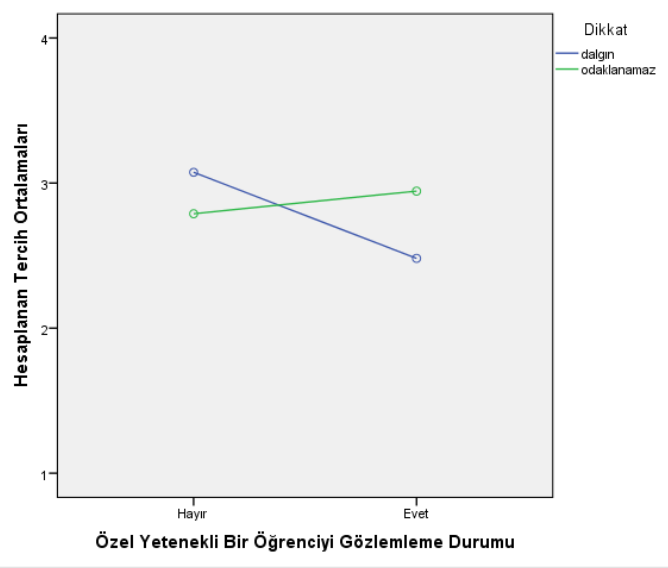

Şekil 10. Öğretmen Adaylarının Tercihlerinin Dikkat ve Öğretmen Adayının Özel Yetenekli Öğrenci Gözlemleme Durumu Arasındaki Etkileşimi

Şekil 9'daki grafiğe bakıldığında öğretmen adaylarının profile konu edilen özellikten etkilenerek kadın öğretmen adaylarının matematik becerisi olan öğrenciyi; erkek öğretmen adaylarının da okumaya istekli ve meraklı olan öğrenciyi daha fazla tercih ettikleri anlaşılmaktadır. Sekizinci olarak da öğretmen adaylarının özel yetenekli bir öğrenciyi gözlemleme durumu ile dikkat arasındaki etkileşim etkisi istatistiksel olarak anlamlı bulunmuştur $F(1,170)=5,046, p=0,026, \eta_{\mathbf{p}}{ }^{2}=0,029$ (Bkz. Şekil 10). Özel yetenekli bir öğrenciyi gözlemleyen öğretmen adaylarının tercihleri dalgın olarak betimlenen öğrenci $(\bar{X}=2,49$, $\sigma=1,10)$ ile odaklanma sorunu yaşayan olarak betimlenen öğrenci $(\bar{X}=2,95, \sigma=0,90)$ arasında odaklanma sorunu yaşayan öğrenci yönünde anlamlı bir farklılık göstermiştir. Özel yetenekli bir öğrenciyi gözlemlememiş olan öğretmen adaylarının tercihleri dalgın olarak betimlenen öğrenci $(\bar{X}=3,07, \sigma=0,92)$ ile odaklanma sorunu yaşayan olarak betimlenen öğrenci $(\bar{X}=2,79$, 
$\sigma=1,03$ ) arasında dalgın olarak betimlenen öğrenci yönünde anlamlı bir farklılık göstermiştir. Şekil 10'daki grafiğe bakıldığında öğretmen adaylarının öğrencinin dikkat durumundan etkilenerek özel yetenekli öğrenciyi gözlemlemiş olan öğretmen adaylarının odaklanamayan öğrenciyi; özel yetenekli öğrenciyi gözlemlememiş olan öğretmen adaylarının da dalgın öğrenciyi daha fazla tercih ettikleri anlaşılmaktadır.

Dokuzuncu bulgu olarak, öğretmen adaylarının özel yetenekli bir tanıdığa sahip olma durumu ile öğrenci duyguları arasındaki etkileşim etkisi istatistiksel olarak anlamlı bulunmuştur $F(1,170)=6,537, p=0,011, \eta_{\mathbf{p}}{ }^{2}=0,037$. Özel yetenekli bir yakını/tanıdığ olan öğretmen adaylarının tercihleri, olgun davranışlar sergilemeyen öğrenci $(\bar{X}=2,67, \sigma=1,03)$ ile yoğun duygusal tepkiler veren hisli öğrenci $(\bar{X}=2,04, \sigma=1,13)$ arasında olgun davranışlar sergilemeyen öğrenci yönünde anlamlı bir farklılık göstermiştir. Özel yetenekli bir yakını/tanıdığı olmayan öğretmen adaylarının tercihleri de, olgun davranışlar sergilemeyen öğrenci $(\bar{X}=1,93, \sigma=1,00)$ ile yoğun duygusal tepkiler veren hisli öğrenci $(\bar{X}=2,28, \sigma=1,14)$ arasında yoğun duygusal tepkiler veren hisli öğrenci yönünde anlamlı bir farklılık göstermiştir. Bu etkileşim Şekil 11'de verilmiştir.

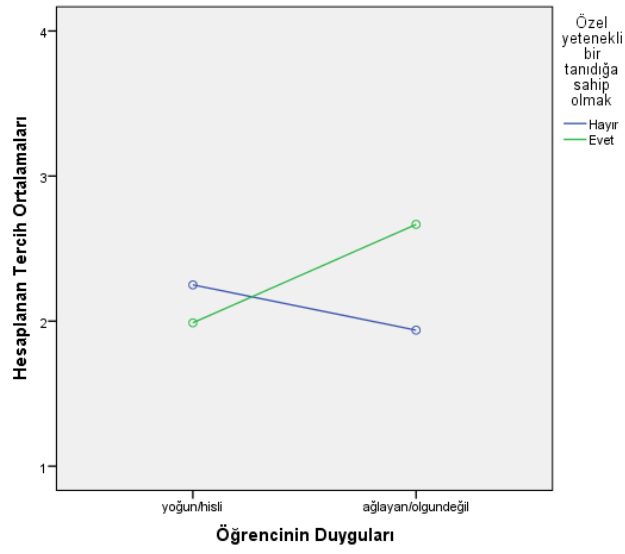

Şekil 11. Öğretmen Adaylarının Tercihlerinin Duygular ve Öğretmen Adayının Özel Yetenekli Tanıdığa/Yakına Sahip Olması Arasındaki Etkileşimi

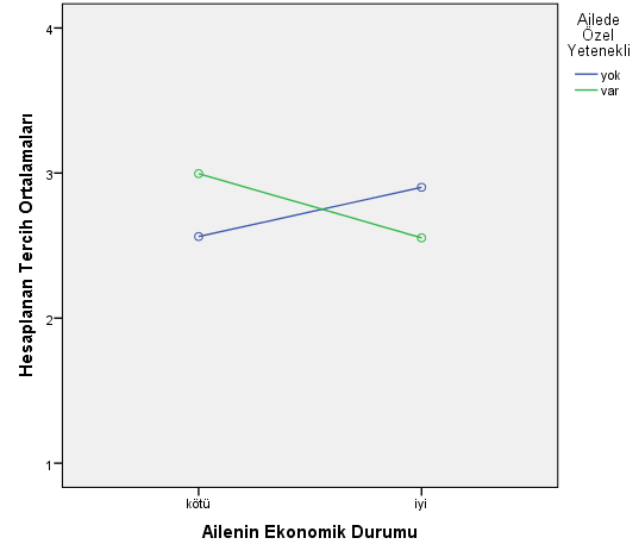

Şekil 12. Öğretmen Adaylarının Tercihlerinin Ailenin Ekonomik Durumu ve Ailede Özel Yetenek Geçmişi Arasındaki Etkileşimi

Şekil 11'deki grafiğe bakıldığında öğretmen adaylarının öğrencinin duygularından etkilenerek özel yetenekli bir yakını/tanıdığı olan öğretmen adaylarının olgun davranışlar sergilemeyen öğrenciyi; özel yetenekli bir yakını/tanıdığı olmayan öğretmen adaylarının ise yoğun duygusal tepkiler veren hisli öğrenciyi daha fazla tercih ettikleri anlaşılmaktadır. Son olarak, ailenin ekonomik durumu ile ailede özel yetenek geçmişi arasındaki etkileşim etkisi istatistiksel olarak anlamlı bulunmuştur $F(1,170)=4,348, p=0,039, \eta_{\mathbf{p}}{ }^{2}=0,025$ (Bkz. Şekil 12). 
Ailenin ekonomik durumu kötü olduğunda, öğretmen adaylarının tercihleri; ailesinde tanılanmış bir özel yetenekli bulunan öğrenci $(\bar{X}=2,80, \sigma=1,03)$ ile ailesinde hiç özel yetenekli bulunmayan öğrenci $(\bar{X}=2,62, \sigma=1,02)$ arasında ailesinde tanılanmış bir özel yetenekli bulunan öğrenci yönünde anlamlı bir farklılık göstermiştir. Ailenin ekonomik durumu iyi olduğunda ise, tercihler; ailesinde tanılanmış bir özel yetenekli bulunan öğrenci $(\bar{X}=2,59, \sigma=0,99)$ ile ailesinde hiç özel yetenekli bulunmayan öğrenci $(\bar{X}=2,83, \sigma=0,88)$ arasında ailesinde tanılanmış bir özel yetenekli bulunmayan öğrenci yönünde anlamlı bir farklılık göstermiştir. Bu etkileşimin verildiği Şekil 12'deki grafiğe bakıldığında öğretmen adaylarının ailenin ekonomik durumu ve ailedeki özel yetenek geçmişinden etkilenerek ailesinin ekonomik durumu iyi fakat ailede tanılanmış bir özel yetenekli olmayan öğrenci ile ailesinin ekonomik durumu kötü fakat ailede tanılanmış bir özel yetenekli olan öğrenciyi diğer durumlara kıyasla daha fazla tercih ettikleri anlaşılmaktadır.

\section{Tartışma ve Sonuç}

$\mathrm{Bu}$ araştırmanın amacı öğretmen adaylarının özel yetenekli öğrenciyi aday gösterme tercihlerini etkileyen faktörleri ortaya çıkarmaktı. Profiller, hem genel hem de versiyonlar bazından bakıldığında, çok yüksek ortalamalara ulaşamamış olup; adayların özel yetenekli öğrenci özelliklerini tanımakta zorlandıklarını düşündürmektedir. Profillere konu olan değişkenler bazından bakıldığında ise cinsiyet, beceri alanı, organizasyon, merak, duygular, sosyo-ekonomik durum, özel yetenekli bir öğrenciyi gözlemlemiş olmak ve özel yetenekli bir yakına/tanıdığa sahip olmak, aday gösterme tercihlerini etkileyerek öğretmen adaylarının tercihlerinde farklılaşmalara neden olmuştur.

\section{Profillerin Tercih Edilme Düzeyleri}

$\mathrm{Bu}$ araştırmada kullanılan öğrenci profillerinin ortalamaları genel olarak çok yüksek değerler almamıştır. Bunun öğretmen adaylarının özel yeteneklilere yönelik eğitim ve deneyim eksikliklerinden kaynaklanmış olabileceği düşünülebilir. Çünkü öğretmen adaylarının öğretmenlere kıyasla profildeki öğrenciyi aday göstermeye daha az eğilimli oldukları (Siegle vd., 2010) ve öğretmen yetiştirme programları dahilinde sadece özel eğitim dersi aldıkları (Demirhan vd., 2016) göz önüne alındığında, farklı özel gereksinim tanı türlerinden sadece biri olan özel yetenekliler alanına yeni bir giriş yapmış olmaları ve özel yeteneklilere ilişkin detaylı bir eğitime maruz bırakılamamış olmalarının da profillerin genel olarak yüksek ortalamalar almamış olması üzerinde etkili olduğu düşünülebilir. Öte yandan, öğrenci profilleri arasından 
öğretmen adayları tarafından en az ve en fazla tercih edilenler Erdimez’in (2017) bulgusu ile karşılaştırıldığında farklılık göstermektedir. Bu farklılığın nedeni olarak öğretmen adaylarının özel yetenek algılarının branşlara göre farklılaşmış olması gösterilebilir. Çünkü, Erdimez’in araştırmasına kıyasla bu araştırma farklı branşlardan öğretmen adaylarının katılımı ile gerçekleştirilmiştir. Bu durumun da doğal olarak farklı perspektiflerden değerlendirmeleri beraberinde getirdiğinden böyle bir değişime neden olduğu düşünülebilir. Buradan hareketle, öğretmen adaylarının özel yetenekli öğrencilerin genel özelliklerinin yansıra öğretmen adayının eğitim aldığı branş ile ilişkili olan özel yetenek alanlarına yönelik özellikler üzerinde de farkındalık kazandırılmalarına ihtiyaçları olduğu öne sürülebilir.

\section{Cinsiyetin Aday Gösterme Tercihlerine Etkisi}

Öğrencinin merak duyduğu derse göre özel yetenekli olarak aday gösterilmesi öğretmen adayının cinsiyetine göre farklılaşmaktadır. Örneğin, erkek öğretmen adayları, fen bilimleri dersine merak duyan bir öğrenciyi diğer derslere kıyasla daha az tercih etmişlerdir. Halbuki, fen bilimleri alanında buluşlar yapan bilim insanı algısının adayların tercihlerinin fen bilimleri dersi üzerinde de en az diğerleri kadar yoğunlaşmasına neden olması beklenebilirdi. Belki de bunun nedeni olarak, adayların bilim insanlarını özel yetenekli olarak görme eğiliminde olmamaları ve böylece bu iki durum arasında bir bağlantı kuramamış olmaları düşünülebilir. Buradan hareketle öğretmen adaylarının özel yetenekli olmayı belirgin derslerle daha fazla ilişkili gördüklerini düşünmek mümkündür. Katılımcıların farklı öğretmenlik programlarında eğitim alıyor olmaları da bu bulgunun bir nedeni olarak düşünülebilir ve doğal olarak öğretmenlik branşlarına göre katılımcıların aday gösterme tercihlerindeki öznelliklerin ortaya konulmasının önemine bir vurgu yapılabilir. Dahası, tercihlerin katılımcının cinsiyeti değişkeni temelinde farklılaşması Erdimez'in (2017) bulgusuyla çelişmekte; Siegle vd.’nin (2010) bulgusu ile paralellik göstermekte olup, merak duyulan derse göre farklılaşmıştır. Bu da öğretmen adaylarının "özel yeteneğin farklı özel yetenek alanlarında ortaya çıkabileceği”" ve "herhangi bir ya da birden fazla derse özgü olarak özel yeteneğin gelişebileceği” bilgisinden uzak olduklarına işaret etmektedir.

Bunun yanı sıra, öğretmen adayları karşı cinsten olan öğrenciyi hemcinsi olan öğrenciye kıyasla özel yetenekli olmaya daha uygun bulmuşlardır. Bu bulgu, Bianco vd. (2011), Powell ve Siegle’ın (2000) ve Erdimez’in (2017) bulguları ile örtüşmekte fakat Hernández-Torrano ve Tursunbayeva'nın (2016) araştırma bulgusu ile çelişmektedir. Bu araştırmada öğretmen adaylarının cinsiyet ile birlikte bir beceri alanından etkilenerek belirgin bir profile (matematik 
becerilerine sahip olan kadın öğrenci) daha fazla anlam yüklemiş olmaları da, Powell ve Siegle'ın (2000) araştırmasını destekler niteliktedir. “Öğrencinin cinsiyeti” ile diğer bir değişken olarak "öğrencinin daha düzenli ve organize olması" da birlikte ele alındığında öğretmen adaylarının tercihlerini etkilediği görülmektedir. Bu bulgu da Erdimez’in (2017) “cinsiyet değişkeni ile birlikte düzensiz öğrencinin daha fazla tercih edilmiş olması” bulgusuyla benzerlik göstermektedir. Bu bulgular ışığında da öğretmen adaylarının özel yetenekli olmaya ilişkin bazı özellikleri cinsiyetten bağımsız bir şekilde değerlendiremeyerek nesnel davranamadıkları söylenebilir.

\section{Sosyo-Ekonomik Durumun Aday Gösterme Tercihlerine Etkisi}

Öğretmen adaylarının tercihlerinde profilde verilen öğrencinin sosyo-ekonomik durumunun (ailenin ekonomik durumu ve ailede özel yetenekli olarak tanılanmış birinin olması) belirgin bir etken olması dikkat çekicidir. İlginç bir şekilde adayların, profildeki öğrencinin sosyo-ekonomik durumuna ilişkin bilgileri birbirinden bağımsız olarak değil de etkileşimli olarak değerlendirerek karar verdikleri anlaşılmaktadır. Bunu da aday gösterme sürecinde öğrencilerin aile özelliklerine ilişkin demografik bilgilerin sadece sosyal ya da ekonomik seviye ile sınırlı tutulmayıp; özellikle ailedeki diğer bireylerin ilgi, merak, yetenek ve belki de başarılarına ilişkin diğer bazı demografik bilgilerin de değerlendirmeye alınmasının daha etkili aday göstermeleri sağlayabileceği şeklinde yorumlamak mümkündür. Bu bulgu, Siegle ve Powell'ın (2004) özel yetenekli olmanın alışılmadık durum ya da davranışlarla ilişkilendiriliyor olması ile Siegle vd.’nin (2010) düşük sosyo-ekonomik düzeydeki ailelerin çocuklarının daha fazla tercih ediliyor olmaları konusunda benzerlik göstermektedir. Bulgu aynı zamanda McBee (2006) ile Hernández-Torrano ve Tursunbayeva'nın (2016) bulgularının tersi yönde bir duruma işaret etmektedir.

\section{Özel Yetenekli Öğrenciyi Gözlemlemenin Aday Gösterme Tercihlerine Etkisi}

$\mathrm{Bu}$ araştırmanın ortaya çıkardığı farklı bulgulardan biri de, özel yetenekli bir öğrenciyi gözlemlemiş olmanın tercihler üzerinde bir fark yaratımış olmasıdır. İlginç bir şekilde, özel yetenekli öğrenciyi gözlemleyen öğretmen adaylarının matematik becerileri ile okumaya istekli oluşun her ikisine de birbirine yakın anlamlar yükledikleri fakat hiçbir şekilde özel yetenekli öğrenciyi gözlemlememiş olan adayların belirgin bir şekilde matematik becerilerine sahip olan öğrenciyi daha fazla tercih ettikleri ortaya çıkmıştır. Bu da kısmen benzer bir etkileşimi cinsiyete göre ortaya çıkarmış olan Erdimez'in (2017) bulgusu ile benzerlik göstermektedir. Bu 
durum hem özel yeteneğin farklı alanlara özgü olabileceğinin hem de özellikle iki kere özel öğrencilerden hem öğrenme güçlüğü hem de özel yeteneği olan öğrencilerin fark edilebilmeleri açısından önem taşımaktadır. Çünkü özel yetenekli olmayı belirgin beceri ya da yetenek alanlarıyla bağdaştırmak; diğer yetenek alanlarında özel yetenekli olma potansiyeline sahip öğrencilerin gözden kaçırılmasına neden olabilir. Ya da, beklenen bir alanda belirgin beceriler sergileyemeyen öğrencilerin başka bir alanda özel yetenekli olma potansiyeline sahip olamayacakları gibi yanlış bir algıdan etkilenerek; tanılama süreçlerine yönlendirilmeme gibi bir durum ile karşı karşıya kalmaları muhtemeldir. Ancak bu yöndeki olumsuzlukların bireysel deneyimlerle ortadan kaldırılabileceği; yani özel yetenekli öğrenciyi gözlemlemiş olmanın aday gösterme tercihlerinde nesnel davranmayı ve özel yetenekli olmanın sıklıkla matematik becerileri ile ilişkilendiriliyor olması gibi basmakalıp olarak nitelendirilebilecek önyargıların kırılmasını sağlayabileceği öne sürülebilir. Dolayısıyla öğretmen adaylarının özel yetenekli öğrencileri gözlemlemeye kasıtlı olarak teşvik edilmelerinin ileride aday gösterme süreçlerinde ortaya çıkabilecek öznellikleri ortadan kaldırmak adına fayda sağlayabileceği düşünülebilir.

\section{Özel Yetenekli Bir Tanıdığı/Yakını Olmanın Aday Gösterme Tercihlerine Etkisi}

$\mathrm{Bu}$ araştırmanın ortaya çıkardığı diğer farklı bir bulgu da öğretmen adaylarının tercihlerinin özel yetenekli bir yakına ya da tanıdığa sahip olmasından etkilenmesidir. Öğretmen adayları eğer özel yetenekli bir tanıdıkları varsa, merak alanı ve merak süresi konusunda daha belirgin tercihlerde bulunabilmekte olup; sıra dışı ve uzun süredir merakı olan öğrencinin tercih edilme düzeyi de artmaktadır. Bu durum da sıradan merakları olabilen fakat derin ve uzun süreli bir merak sahibi olan özel yeteneklilerin gözden kaçırılmasına neden olabilir. Halbuki, özel yetenekli öğrenciler sıra dışı meraklara sahip oldukları kadar sıradan meraklara da sahip olabilirler. Kritik olan ve önemsenmesi gereken nokta ise bu merakın derinliğidir. Bu araştırmanın bulgularındaki “merak süresi” ve “merak alanı” ile olan etkileşim; Siegle vd.'nin (2010) araştırma bulgusu ile merak alanı açısından; Erdimez' in (2017) araştırma bulgusu ile merak süresi açısından paralellik göstermiştir.

Öte yandan, öğrencilerin duygusal davranmaları da öğretmen adayının özel yetenekli tanıdığa/yakına sahip olmasından etkilenerek tercihleri etkilemiştir. Çünkü özel yetenekli bir tanıdığı olanların olumlu yöndeki tutumlarının, özel yetenekli olmayı her öğrencide var olabilecek olumlu ya da olumsuz birkaç duygu ve davranış ile sınırlandırmamalarına neden olması beklenebilirdi. Bu da öğretmen adaylarının özel yetenekli öğrencilerin duygusal özelliklerine yönelik yeterli bilgiye sahip olmadıkları ve gözlemledikleri uç duyguları ya da 
durumları özel yetenekli olma ile ilişkilendirme eğiliminde oldukları şeklinde yorumlanabilir. Bu bulgu, Erdimez (2017) ve Siegle vd.'nin (2010) araştırma bulgularından farklılaşan bir bulgudur. Dahası bu bulgu, Gencel ve Satmaz'ın (2017) ortaya çıkarmış olduğu özel yetenekli bir tanıdığı olan öğretmen adaylarının tutumlarının diğerlerine nazaran daha olumlu olduğu bulgusu ile de çelişmektedir.

Sonuç olarak; bu araştırmanın bulguları, öğretmen adaylarının özel yetenekli öğrenci tercihlerinde hem kendi demografik özelliklerinden hem de profillerde verilen öğrenci özelliklerinden etkilendiklerini ve dolayısıyla tercihlerini yaparken öznel davrandıklarını ortaya çıkarmıştır. Bu güncel araştırmanın bulguları, sadece özel eğitim dersi almış olmanın öğretmen adayları için özel yetenekli öğrenci özellikleri ile tanışabilme konusunda belirgin bir yeterlik sağlamadığına da işaret etmektedir. Çünkü toplamda yirmi sekiz ders saatine sığdırılmakta olan özel eğitim dersi, içeriğinde farklı özel gereksinim türlerine konu olmakla beraber; dersin yürütüldüğü dönem içerisinde bir tanı türü için ortalama olarak iki-üç ders saatinden öteye gidilmesi mümkün görünmemektedir. Gear (1978) öğretmenlerin özel yetenekli öğrencilerin özelliklerini tanıma konusunda on saatlik bir eğitim aldıklarında eğitim almayan öğretmenlere kıyasla iki katı daha etkin bir şekilde doğru seçim yapabildiklerini ortaya çıkarmıştır. Fakat Yüksek Öğretim Kurumu (YÖK) tarafindan 2018 yılında yeniden yapılandırılan öğretmenlik lisans programlarına özel yeteneklilere yönelik seçmeli derslerin eklendiği ancak bunun sadece birkaç öğretmenlik programı ile sınırlı kaldığı görülmektedir (YÖK, 2018). Netice olarak, ileride özel yeteneklileri fark edip tanılama süreçlerine yönlendirmesi beklenen öğretmen adaylarının, özellikle öğretmen yetiştirme sürecinde özel yetenekli öğrenci özellikleri ile daha etkili bir şekilde buluşturulmalarına ve onları etkin bir şekilde fark etmelerine yönelik belirgin yeterliklerin kazandırılmasına ihtiyaç vardır.

\section{Öneriler}

$\mathrm{Bu}$ araştırmadan elde edilen bulgular ve sonuç doğrultusunda uygulamaya ve araştırmaya dönük olarak bazı öneriler geliştirilmiştir. Uygulamaya dönük olarak, özel yeteneklilerin özelliklerini tanımaya yönelik daha fazla zamanın ayrılıp; eğitim içeriğine özel yetenek alanlarına ve detaylı bir şekilde öğrenci özelliklerine yer verilerek yapılandırılması daha etkili olabilir. Eğitim sürecinde öğretmenlik branşları ile yakından ilişkili olan özel yetenek alanlarına daha fazla ağırlık verilebilir. Bu eğitim sürecinin içerisine özel yetenekli öğrencilerin fark edilmesine yönelik olarak belirgin becerilerin kazandırılması amacıyla özgün öğrenme hedefleri de eklenebilir. Öğretmen adaylarının okul deneyimi ve öğretmenlik 
uygulaması dersleri kapsamında özel yetenekli öğrencilerin eğitim aldıkları okullarda staj yaparak bu öğrencileri doğrudan gözlemlemeleri sağlanabilir. Araştırmaya dönük olarak ise özel eğitim dersi almış ve almamış öğretmen adaylarının tercihleri karşılaştırılarak özel eğitim dersi almanın özel yetenekli öğrenciyi aday gösterme tercihlerinde nesnel davranmaya etki edip etmediği ortaya çıkarılabilir. Ayrıca bu tür bir araştırmada sınıf düzeyi de bağımsız bir değişken olarak alınarak lisans eğitimi süresince tercihlerdeki değişimin boylamsal olarak ortaya konulması da sağlanabilir. Öğretmen adayları ve/veya öğretmenlerin tercihleri branş bazında tarama modelinde ya da karşılaştırmalı olarak araştırılabilir. Özellikle cinsiyetin tercihler üzerindeki etkisini daha net bir şekilde ortaya çıkarmak için kadın ve erkek katılımcıların birbirine yakın sayılarda tutulduğu katılımcılar üzerinde araştırma yapılmasına ihtiyaç vardır. Farklı branşlara özgü yetenek alanlarını temsil eder şekilde öğrenci profilleri hazırlanarak farklı araştırmalara yönelik birer veri toplama aracı olarak kullanılabilir. Bu araştırmadaki ya da geliştirilecek farklı profiller kullanılarak öğretmenler ve öğretmen adayları ile nitel araştırmalar yürütülebilir. Son olarak, ilgili mevzuatta da vurgulandığ üzere özel yetenekli öğrenciyi aday gösterme işlemini yapmakta olan sınıf ve branş öğretmenlerinin tercihlerindeki öznelliklerin ortaya çıkarılabileceği ve bu öğretmenlerin aday göstermedeki başarıları ile tercihlerinde öğrenci özelliklerinden etkilenme durumlarının ilişkisel olarak da incelenebileceği farklı araştırmalar da yürütülebilir.

\section{Makalenin Bilimdeki Konumu}

Özel Eğitim/Özel Yeteneklilerin Eğitimi

\section{Makalenin Bilimdeki Özgünlüğü}

Özel yetenekli öğrencileri eğitim ortamlarında fark etmeleri beklenen öğretmenlerin, öğretmen yetiştirme süreci sonunda buna ne derecede hazır oldukları ve de ne derece yansız yani objektif olarak bu işlemi yerine getirebilme becerisine sahip oldukları konusunda alan yazında sınırlı sayıda araştırma bulunmaktadır. Bu nedenle öğretmen adaylarının öğretmen yetiştirme sürecinde maruz kaldıkları eğitim programlarında bu özel duruma odaklı olarak alınması gereken önlemlerin belirlenmesi için öğretmen adaylarının özel yetenekli öğrencileri aday gösterme tercihlerinde etkili olan faktörler incelenerek ortaya çıkarılmıştır. 


\section{Kaynaklar}

Akar, İ. \& Şengil-Akar, Ş. (2012). İlköğretim okullarında görev yapmakta olan öğretmenlerin üstün yetenek kavramı hakkındaki görüşleri. Kastamonu Eğitim Dergisi, 20(2), 423-436.

Akar, İ. \& Uluman, M. (2013). Sınıf öğretmenlerinin üstün yetenekli öğrencileri doğru aday gösterme durumları. Üstün Yetenekliler Eğitimi Araştırmaları Dergisi, 1(3), 199-212.

Alvidrez, J., \& Weinstein, R. S. (1999). Early teacher perceptions and later student academic achievement. Journal of educational psychology, 91(4), 731.

Betts, G. T., \& Neihart, M. (1988) 'Profiles of the gifted and talented', Gifted Child Quarterly, 32 (2), 248-253.

Bianco, M. (2005). The effects of disability labels on special education and general education teachers' referrals for gifted programs. Learning Disability Quarterly, 28(4), 285-293.

Bianco, M., \& Leech, N. L. (2010). Twice-exceptional learners: Effects of teacher preparation and disability labels on gifted referrals. Teacher education and special education, 33(4), 319-334.

Bianco, M., Harris, B., Garrison-Wade, D., \& Leech, N. (2011). Gifted girls: Gender bias in gifted referrals. Roeper Review, 33(3), 170-181.

Çapan, B. E. (2010). Öğretmen adaylarının üstün yetenekli öğrencilere ilişkin metaforik algıları. Uluslararası Sosyal Araştırmalar Dergisi, 3(12), 140-154.

Dağlığlu, H. E. (1995). İlkokul 2.-5. sınıflara devam eden çocuklar arasında üstün yetenekli olanların belirlenmesi. Yayımlanmamış yüksek lisans tezi, Hacettepe Üniversitesi Sağlık Bilimleri Enstitüsü.

Demirhan, E., Uyanık, G. K., Güngören, Ö. C., \& Erdoğan, D. G. (2016). An examination of pre-service classroom teaching programs in terms of gifted education in Turkey. Journal for the Education of Gifted Young Scientists, 4(2), 15-28.

Duran, A., \& Dağlığlu, H. E. (2017). Okul öncesi öğretmen adaylarının üstün yetenekli çocuklara ilişkin metaforik algıları. Gazi Üniversitesi Gazi Ĕgitim Fakültesi Dergisi, 37(3), 855-881.

Elhoweris, H., Mutua, K., Alsheikh, N., \& Holloway, P. (2005). Effect of children's ethnicity on teachers' referral and recommendation decisions in gifted and talented programs. Remedial and special education, 26(1), 25-31. 
Erdimez, O. (2017). Turkish pre-service elementary school teachers ‘ perceptions of giftedness and factors affecting their referral decisions. Unpublished Dissertation. University of Arizona, Tucson.

Fraenkel, J. R., \& Wallen, N. E. (2006). How to design and evaluate research in education. New York: McGrow-Hill.

Gear, G. H. (1976). Accuracy of teacher judgement in identifying intellectually gifted children: a review of the literature. Gifted Child Quarterly, 20, 478-90.

Gear, G. H. (1978). Effects of training on teachers' accuracy in the identification of gifted children. Gifted Child Quarterly, 22(1), 90-97.

Gencel, İ. E., \& Satmaz, İ. (2017). Öğretmen adaylarının üstün yetenekli öğrencilerin eğitimine yönelik tutumları. Uluslararası Eğitim Programları ve Öğretim Çalışmaları Dergisi, 7(14), 49-62.

Gökdere, M., \& Ayvacı, H. Ş. (2004). Sınıf öğretmenlerinin üstün yetenekli çocuklar ve özellikleri ile ilgili bilgi seviyelerinin belirlenmesi. Ondokuz Mayıs Üniversitesi Ĕ̈itim Fakültesi Dergisi, 18, 17-26.

Gürsel, O. (2008). Özel eğitimde değerlendirme. Diken, İ. H. (Ed). Özel ĕgitim içinde (s. 2958). Ankara: Pegem Akademi.

Hernández-Torrano, D., \& Tursunbayeva, X. (2016). Are teachers biased when nominating students for gifted services? Evidence from Kazakhstan. High Ability Studies, 27(2), 165177.

Jacobs, J. C. (1971). Effectiveness of teacher and parent identification of gifted children as a function of school level. Psychology in the Schools, 8 (2), 140-142.

Koca, C. (2009). Gender interaction in coed physical education: a study in Turkey. Adolescence, 44(173), 165-185.

McBee, M. T. (2006). A descriptive analysis of referral sources for gifted identification screening by race and socioeconomic status. Journal of Secondary Gifted Education, 17(2), 103-111.

MEB. (2016). Bilim ve sanat merkezleri yönergesi. Ankara: MEB Özel Eğitim ve Rehberlik Hizmetleri Genel Müdürlüğü.

MEB. (2018). Bilim ve sanat merkezleri ögrenci tanılama ve yerleştirme kılavuzu 2018-2019. Ankara: MEB Özel Eğitim ve Rehberlik Hizmetleri Genel Müdürlüğü. 
Metin, N., Şenol, F. B., \& İnce, E. (2017). Öğretmen adaylarının üstün yetenekli çocukların eğitimine yönelik tutumlarının belirlenmesi. Kuramsal Eğitimbilim Dergisi, 10(1), 95116.

Olivares, R. A., \& Rosenthal, N. (1992). Gender Equity and Classroom Experiences: A Review of Research. (ERIC Reproduction Service No: 366701). 19.09.2018 tarihinde https://files.eric.ed.gov/fulltext/ED366701.pdf bağlantısından erişildi.

Pegnato, C. W., \& Birch, J. W. (1959). Locating gifted children in junior high schools - a comparison of methods. Exceptional Children, 25, 300-304.

Powell, T., \& Siegle, D. (2000). Teacher bias in identifying gifted and talented students. The National Research Center on the Gifted and Talented Newsletter, Spring, 13-15.

Rohrer, J. C. (1995). Primary teacher conceptions of giftedness: Image, evidence and nonevidence. Journal for the Education of the Gifted, 18(3), 269-283.

Sadker, M., \& Sadker, D. (1993). Fair and Square? Creating a Nonsexist Classroom. Instructor, 102(7), 44-45,67-68.

Schack, G. D., \& Starko, A. J. (1990). Identification of gifted students: An analysis of criteria preferred by preservice teachers, classroom teachers, and teachers of the gifted. Journal for the Education of the Gifted, 13, 346-363.

Siegle, D., \& Powell, T. (2004). Exploring teacher biases when nominating students for gifted programs. Gifted Child Quarterly, 48(1), 21-29.

Siegle, D., Moore, M., Mann, L. R., \& Wilson, E. H. (2010). Factors that influence in-service and pre-service teachers' nominations of students for the gifted and talented programs. Journal for the Education of the Gifted, 33, 337-360.

Tortop, H. S. (2014). Öğretmen adaylarının üstün yetenekli ve çok kültürlü eğitime ilişkin tutumları. Üstün Yetenekliler Ĕgitimi ve Araştırmaları Dergisi, 2(2), 16-26.

Yıldırım, H. İ., \& Öz, A. Ş. (2018). Öğretmen adaylarının özel yeteneklilerin eğitimine ilişkin tutumlarının incelenmesi. Milli Eğitim Dergisi, 47(özel sayı 1), 91-108.

YÖK. (2018). Yeni ögrretmen yetiştirme lisans programlarl. 15.03 .2019 tarihinde https://www.yok.gov.tr/kurumsal/idari-birimler/egitim-ogretim-dairesi/yeni-ogretmenyetistirme-lisans-programlari adresinden erişildi. 


\section{Ek 1: Öğrenci Profilleri Anketinde Yer Alan Profiller}

Profil 1 (cinsiyet x ders): Kadir (Keriman) sessiz ve içine kapanık bir öğrencidir. Konuşulan konuyu bilmesine rağmen çoğu defa fikirler arasında kaybolur ve az önce ne söylendiğini hatırlamaz. Yaptığı yorumlar ise çoğu zaman konuyla alakasızdır. Kadir (Keriman), her çeşit kitabı okumayı sever. Özellikle (Hayat Bilgisi, Türkçe, Matematik veya Fen Bilgisi ) dersine çok meraklıdır. Düzenli bir öğrenci olmamasına ve nadiren ödevlerini yapmasına rağmen sınavlarda iyi puan almaktadır. Onun için arkadaşları ile vakit geçirmek çok da tercih edilen bir şey değildir. Teneffüslerde yalnız başına okul içinde gezmeyi veya öğretmenleri ile konuşmayı tercih eder.

Profil 2 (cinsiyet x sınıf düzeyi): Betül (Bilal) derse aktif katılan (birinci, ikinci, üçüncü, dördüncü) sınıf öğrencisidir. Derste işlenen birçok konu hakkında çok akıllıca sorular sorar. Arkadaşlarının yeni bir konuya geçmelerinin üzerinden çok zaman geçmesine rağmen o hâlâ aynı konu ile ilgilenmeye devam eder. Bu durum Betül (Bilal) için çok can sıkıcıdır, çünkü öğrenmesi gerekenler için kendisine yeterince zaman verilmediğini düşünmektedir. Betül (Bilal) birçok farklı fikir ve olay arasındaki ilişkiyi görebilmektedir. Etrafındaki insanlar tarafından çok anlaşılmayan ve takdir edilmeyen farklı bir espiri anlayışına sahiptir.

Profil 3 (cinsiyet x matematik x okuma): Melek (Mustafa) çok konuşkan bir öğrencidir. Geniş bir kelime hazinesine sahiptir ve kelime oyunları yapmaktan hoşlanır. Onun yaptığı espriler genellikle etrafındaki insanlar tarafından pek beğenilmez ve onaylanmaz. Sınıf içi tartışmalarda genellikle bütün sınıfı domine etmeye çalışır ve başkalarının fikirlerinin görünmemesine sebep olur. Okumaya çok hevesli ve arzulu olmasına rağmen okuduğu kitaplar genellikle yaşına uygun görünmemektedir. (Okuma hevesinden bahsetme). Matematik ile ilgili kavramları çok hızlı bir şekilde anlayabilmesine rağmen, süre ile sınırlandırılmış matematik testlerinde genelde iyi performans gösterememektedir (Matematikten bahsetme). Melek (Mustafa) ödevlerini zamanında teslim eder ve ödevlerinin kalitesi ödevden ödeve farkl1l1k gösterir.

Profil 4 (cinsiyet x merak alanı x merak süresi): Demet (Davut) kartallara (köpeklere) ikinci sınıftan (anasınıfından) itibaren aşırı derecede meraklı olan dördüncü sınıf öğrencisidir. Odasının duvarları kartal (köpek) posterleri ile kaplıdır. Kartallar (köpekler) hakkında okul kütüphanesi ve şehirdeki halk kütüphanesinde bulunan bütün kitapları okumuştur ve şimdi de çevre illerin kütüphanelerinden kartallar (köpekler) hakkındaki kitapları sipariş etmeye 
başlamıştır. Her konuşmaya veya ödeve bir şekilde kartalları (köpekleri) yerleştirmeye çalışmaktadır. Yazdığı cümleler, yaptığı ödevler hep kartallar (köpekler) hakkındadır. Demet (Davut) kartallara (köpeklere) o kadar çok ilgi duymaktadır ki bir şekilde onları matematik ve fen bilgisi derslerine bile dâhil etmektedir. Sınıf arkadaşları kartallar (köpekler) ile ilgili konuşmalardan bıkmışlar ve Demet (Davut)'e yeni bir ilgi alanı bulmasını tavsiye etmektedirler ama O, kartallar (köpekler ) hakkında ilk günkü kadar meraklıdır.

Profil 5 (cinsiyet $x$ organize olma): Sami (Selma) öğrenmeyi seven ve birçok arkadaşı olan parlak bir dördüncü sınıf öğrencisidir. Sami (Selma) düzenli bir öğrencidir. (Genelde masasını düzenli tutmada zorlanır ve ödevlerini yanlış yerlere koyar. Ödevleri genelde düzenli değildir.). Sami (Selma) cana yakın ve sosyal biridir. Problem çözme becerileri mükemmel ve okumaya çok isteklidir. Sami (Selma) tarihi mekânlara çok meraklıdır. Türkiye'deki bütün sarayların bulunduğu şehirleri ve bu sarayların yapılış tarihlerini ezbere bilir ama kendi okulunda organize edilen etkinliklerin tarih ve saatlerini hatırlamakta zorluk çekmektedir.

Profil 6 (cinsiyet $\mathbf{x}$ ders $\mathbf{x}$ kararlılık): Necip (Nalan) mükemmel matematik becerilerine sahip (okumaya çok meraklı ve istekli olan) beşinci sınıföğrencisidir. Okulda başarılı ve ödevlerini düzenli yapan bir öğrencidir. Çoğu kez kendi görüşlerini açıklamaktan çekinir ve fikirleri arkadaşlarının etkisiyle çok çabuk baskı altına alınır. (O kendi fikirlerini korkusuzca dile getirir ve bazen bu kararlılığı arkadaşları ile arasında gerginliğe yol açar). Necip (Nalan) balıkları çok sever ve bulduğu her firsatta balıklar hakkında bir şeyler okur. Hatta anne ve babasını arka bahçelerinde küçük bir balık havuzu yapma konusunda ikna etmiştir.

Profil 7 (cinsiyet x dikkat): Gülay (Galip) birçok konuya ilgisi olan yaşama sevinciyle dolu bir dördüncü sınıf öğrencisidir. Onun son zamanlardaki tutkusu balina ve yunuslardır. Her gün sahile vuran balinalar ile ilgili haberleri takip etmektedir. Öğlen arasında okuldaki arkadaşlarını "Balinaları koruyalım" kampanyasına katılmaları için ikna etmeye çalışmaktadır. Gülay (Galip)'ın çok farklı alanlara olan ilgisi sınıf içerisinde onun bir konuyu veya ödevi tamamlamadan başka bir konuya yönelmesine sebep olmaktadır. Genelde dalgın ve düşüncelidir. (Gülay /Galip derste genellikle verilen etkinliği tamamlamaz, önceki etkinliği veya ödevi tamamlamadığını fark etmeden bir sonraki etkinliğe geçer. Gülay /Galip genellikle derste odaklanamamaktadır). Gülay (Galip)'ın ödevlerinden onun matematik problemlerini çözmede yetenekli olduğu anlaşılmaktadır. Yaratıcı hikâye yazma konusunda ayrıntılı fikirleri olmasına rağmen bu fikirlerini çok nadir yazıya dökmektedir. 
Profil 8 (cinsiyet $x$ öğrenciler üzerindeki kontrolü): Leyla (Lokman) tarih dersine aşırı derecede ilgi duyan bir dördüncü sınıf öğrencisidir. Osmanlı İmparatorluğu’nu yöneten bütün padişahların adlarını ve imparatorluğu yönettikleri seneleri ezbere bilmektedir. Leyla (Lokman) dominant (lider olarak doğmuş) bir kişiliktir ve gittiği yolda arkadaşlarının kendisini takip etmesini sağlayabilecek biridir. Leyla (Lokman) kompozisyon yazma ve bilgileri hatırlama konusunda çok mükemmel becerilere sahiptir.

Profil 9 (Cinsiyet x duygular): Ertan (Eylül) çok mükemmel okuma becerileri olan bir dördüncü sınıf öğrencisidir. Bütün kitap türlerini bir çırpıda okuyup bitirmekle beraber en çok fabl türünü sevmektedir. Ertan (Eylül) olumsuz durumlar karşısında çok yoğun duygusal tepkiler gösteren hisli bir kişidir. (Ertan /Eylül kendi istediği olmayınca kolayca ağlayan, yaşına göre olgun olmayan biridir). Ertan (Eylül) ödevlerini düzgün bir şekilde yapan ve zamanında teslim eden bir öğrencidir.

Profil 10 (cinsiyet $\mathbf{x}$ arkadaş ilişkileri): Cemal (Canan) mutlu ve parlak bir üçüncü sınıf öğrencisidir. Sınıf arkadaşlarıyla çok iyi anlaşamamaktadır ve çoğu kez konuyu anlamayan arkadaşlarına yardım etmesi istendiğinde bu duruma öfkelenmektedir ( $\mathbf{O}$ arkadaşlarıyla çok iyi geçinen ve konuyu anlamayan arkadaşlarına her zaman yardımcı olmaya çalışan bir öğrencidir). Cemal (Canan) bilim kurgu olmayan kitapları okumaktan hoşlanır ve bu kitaplardan öğrendiği bilgileri sınıf arkadaşları ile paylaşmak ister. Cemal (Canan) gün içerisinde birçok kez öğretmenin sözünü yarıda kesip ona ve sınıf arkadaşlarına okuyup öğrendiği şeyleri anlatmaya çalışmaktadır. Öğretmen, Cemal (Canan)’ in öğrenme aşkını her ne kadar takdir etse de, sınıfın düzenini bozan bu tavrının diğer öğrenciler için problem olduğunu düşünmektedir.

Profil 11 (ekonomik durum $\mathbf{x}$ ailede özel yetenek geçmişi): Azra, anne-babası ve lise ikinci sınıfa giden kardeşi ile beraber yaşayan düzenli ve parlak bir ikinci sınıf öğrencisidir. Ailesinin ekonomik durumu iyidir (kötüdür). Azra duygusal, empatik ve arkadaşları tarafından kabul gören bir öğrencidir. Derslerinde üstün başarı gösteren meraklı biridir. Azra kaplumbağalara aşırı derecede ilgi duyan ve zamanının birçoğunu bilim kanalını izleyerek geçiren biridir. Matematik alanında özel yetenekli olan abisiyle çok iyi geçinir (Özel yetenekliler programına kabul edilirse, ailesinde özel yetenekliler programına kabul edilen ilk kişi olacaktır). 


\section{Summary}

\section{Statement of the Problem}

Teacher-training programs in Turkey provide only a special education course that covers different types of special needs, which includes giftedness as well (Demirhan, Uyanı, Güngören \& Erdoğan, 2016). However, focusing on teacher training years, research on prospective teachers regarding to giftedness mostly focused on their views, perceptions, metaphorical perceptions, attitudes towards gifted education. Only one study was found to have conducted on referral decisions of prospective classroom teachers (Erdimez, 2017) and concluded that student's gender, passion, ability and personal characteristics influenced prospective classroom teachers' decisions. However, this research study focused on $4^{\text {th }}$ grade prospective teachers referral decisions for gifted students, whom expected to have the fresh potential to realize and nominate students to identification processes for programs for gifted students. Previous studies showed that in-service teachers are biased in their referral decisions. One solution to this problem could be to address it during teacher training years. From this point of view, it was aimed to reveal whether prospective teachers' are biased in their referral decisions with regard to considering them as future nominators of gifted students. Two research questions that were focused are given below.

1. Which student profiles did prospective teachers rate least and most?

2. Which demographic and student characteristics did influence prospective teachers' referral decisions?

\section{Methodology}

This research study was a survey method. Participants were 178 fourth grade prospective teachers, 139 female and 39 male. All participants have taken and completed the special education course. Data were collected online via Student Profiles Survey, which developed by Siegle et al. (2010) and was adapted to Turkish language by Erdimez (2017) that includes eleven different student profiles in which are embedded with different characteristics of gifted students. Three and four ways of analysis of variance, mean and standard deviations were used to analyse the data.

\section{Findings}

The most rated profile was found to be the second profile's fourth $(\overline{\mathrm{X}}=3.44)$, fifth $(\bar{X}=3.08)$ and second version $(\bar{X}=3.08)$, and the least rated profile was found to be the sixth 
profile's third ( $\overline{\mathrm{X}}=1.71)$, second $(\overline{\mathrm{X}}=1.73)$ and fifth version $(\overline{\mathrm{X}}=1.82)$. The interaction effect; between student's subject and prospective teacher's gender $F(3,168)=3.093, p=.029, \eta_{\mathbf{p}}{ }^{2}=.052$, between student's gender and prospective teacher's gender $F(1,168)=5.279, p=.023, \eta_{\mathbf{p}}{ }^{2}=.030$, and between student's area of passion and length of passion $F(1,168)=4.978, p=.027, \eta_{\mathbf{p}}{ }^{2}=.029$ were found statistically significant. Also, the interaction effect; between student's area of passion and length of passion and prospective teacher's having a relative/being familiar someone identified as gifted $F(1,168)=6.084, p=.015, \eta_{\mathbf{p}}{ }^{2}=.035$, between student's gender and organization $F(1,170)=4.172, p=.043, \eta_{\mathbf{p}}{ }^{2}=.024$, and between student's gender and prospective teacher's having observed a gifted student $F(1,170)=4.455, p=.036, \eta_{\mathbf{p}}{ }^{2}=.026$ were found statistically significant. Additionally, the interaction effect; between student's ability area and prospective teacher's having observed a gifted student $F(1,170)=5.390, p=.021, \eta_{\mathbf{p}}{ }^{2}=.031$, between student's ability area and prospective teacher's gender $F(1,170)=4.224, p=.041$, $\eta_{\mathbf{p}}{ }^{2}=.024$, and between student's attention and prospective teacher's having observed a gifted student $F(1,170)=5.046, p=.026, \eta_{\mathbf{p}}{ }^{2}=.029$ were found statistically significant. Moreover, the interaction effect; between student's emotions and prospective teacher's having a relative/being familiar someone identified as gifted $F(1,170)=6.537, p=.011, \eta_{\mathbf{p}}{ }^{2}=.037$, and between student's economic status and family history in gifted education $F(1,170)=4.348, p=.039, \eta_{\mathbf{p}}{ }^{2}=.025$ were found statistically significant.

\section{Discussion \& Conclusion}

Similar to Siegle et al.'s (2010) research findings, prospective teachers do not have a tendency of realizing gifted students characteristics. The most rated (second) and the least rated (sixth) profiles differed from Erdimez's (2017) research findings. Male prospective teachers rated Turkish higher than science and rated Turkish subject higher than female prospective teachers did, which is contrary to Erdimez's (2017) findings and partially similar to Siegle et al.'s (2010) findings. Prospective teachers who observed a gifted student rated the student with math skills higher than the student with reading skills, and they also rated female student with math skills higher than male one. Initial finding is partially similar to Erdimez's (2017) finding and latter was parallel to Powell and Siegle’s (2000) finding. Male prospective teachers rated female students and female prospective teachers rated male students higher, which is similar to Bianco et al. (2011) and Powell and Siegle’s (2000) findings, parallel to Erdimez's (2017) findings and contrary to Hernández-Torrano and Tursunbayeva’s (2016) findings. Prospective teachers, who has a relative/being familiar someone identified as gifted, rated the student who 
is interested in eagles from kindergarten years higher than the student who is interested in dogs, which is parallel to Siegle et al.’s (2010) findings on area of passion; and Erdimez's (2017) findings on length of passion. Unorganized male student was rated higher than others, as similar to Erdimez's (2017) findings except for gender variable. Similar to Siegle et al.'s (2010) findings, prospective teachers, who observed a gifted student, rated unfocused student higher; prospective teachers, who did not observe a gifted student, rated preoccupied student higher. Similar to Siegle et al.’s (2010) and Erdimez’s (2017) findings, prospective teachers who has a relative/being familiar someone identified as gifted, referral decisions but differed towards the student described as immature. In support to Siegle and Powell's (2004) findings on relating giftedness with extraordinary conditions, prospective teachers' rated the student from low economic status if he/she has a sibling identified as gifted; and the student from high economic status if he/she has no sibling identified as gifted higher. This finding is also similar to Siegle et al.'s (2010) finding and it indicates a different aspect compared to McBee’s (2006) finding. Current research revealed that prospective teachers were influenced by their and the students' characteristics and are biased in their referral decisions. The author recommends a course focusing only on gifted students and their characteristics for every teacher training programs, an experience with a gifted student such as observing one of them during teaching experience or school experience. Comparing prospective teachers' and in-service teachers' referral decisions for each teaching branch and in-service classroom teachers' referral decisions with regard to their accuracy in nominating the gifted are also recommended for further research. 